\title{
LAS MASCARADAS, FIESTA BARROCA EN SEVILla
}

\author{
Francisco Ollero Lobato
}

Universidad Pablo de Olavide de Sevilla

Resumen: El presente artículo estudia el cortejo festivo de las mascaradas en el contexto urbano de la ciudad de Sevilla. Se indaga sobre los antecedentes de este espectáculo, sus características formales y su relación con otras fiestas y la comedia. Se analiza los contenidos y el papel de la alegoría mitológica para la unidad temática de cada manifestación festiva. Por último, se reflexiona sobre la evolución de esta tipología festiva y los aspectos dinámicos y conflictivos de su desarrollo, en especial a lo largo del siglo XVIII.

Palabras clave: Sevilla, celebraciones públicas, arte barroco, fiesta.

ABSTRACT: This article studies the festive procession called masquerade in the city of Seville during the seventeenth and eighteenth centuries. It investigates the history of these festivals, their formal characteristics and their relation to other celebrations of this period. It analyzes the content and the role of mythological allegory for the thematic unity of each festive event. Finally, it examines the evolution of this type of festive ceremonies, as well conflicting aspects of their development, especially during the eighteenth century.

Keywords: Seville, masquerade, festivals, Baroque Art. 
$\mathrm{D}$ el relativamente escaso caudal de imágenes de la fiesta sevillana en el Barroco, la mayor parte de las mismas -la serie encargada por la Real Fábrica de Tabacos y realizada por Domingo Martínez y otros pintores acreditados de la ciudad en el siglo XviII, y las ilustraciones para el Aplauso real... de 1742 inventadas por aquel pintor, ${ }^{1}$ corresponden a la representación de aspectos diversos del tipo festivo conocido como mascaradas. Sirva esta referencia para sustentar el papel fundamental de estos cortejos en el conjunto del mundo festivo de la capital sureña.

Las mascaradas consistían fundamentalmente en un cortejo festivo, que celebraba un acontecimiento feliz vinculado al trono o al altar, donde, a pie o a caballo, participaban diferentes personajes caracterizados, y en donde se declamaban textos, líricos o dramáticos, se oía música o se presenciaban danzas y mímica. Los principales hitos del significado de la mascarada eran los carros, adornados y compuestos por figurantes o actores, que representaban contenidos de carácter serio o jocoso. Si se entiende por extensión esta fiesta como representación dramática, la mascarada se inscribe en el grupo de las mojigangas, piezas teatrales breves y secundarias con respecto a otras de tono más serio, en las que se desarrollaba una idea mediante la parodia de otros géneros. ${ }^{2}$ Constituirá una tipología festiva de extraordinario éxito en el mundo hispánico, desarrollada con diversas variantes y formas, donde coexistían elementos populares con otros provenientes de lo cortesano y aristocrático. ${ }^{3}$

\section{ANTECEDENTES}

El uso de carros para el teatro estaba asociado en Sevilla a la fiesta del Corpus, donde diferentes compañías utilizaban estas escenas móviles para representar autos sacramentales o entremeses en diferentes partes del trayecto, delante del Santísimo o una vez finalizada la procesión, en especial junto a la puerta principal de la catedral, la calle Génova, y la plaza de San Francisco. El espectáculo se efectuaba delante de principales instituciones o personalidades; estas representaciones, si bien en origen parecen que eran sufragadas por las corporaciones laborales de la ciudad, desde mediados del siglo XVI pasaron a ser costeadas por el propio municipio. ${ }^{4}$ Este espectáculo, de enorme populari-

1. Serrera, J. M., Oliver, A. y Portús, J.: Iconografía de Sevilla 1650-1790. Madrid: El Viso, 1989, Números 216 al 223 y 234 al 237 del catálogo, respectivamente.

2. Buezo, C.: La mojiganga dramática. Historia y teoría. Madrid: Universidad complutense, 1991. Buezo, C. (ed.) La mojiganga dramática. De la fiesta al teatro (II Edición). Kassel (Alemania): Reichenberger, 2005; Alonso Asenjo, J.: «Base y despegue del teatro como instrumento educativo en la Edad Moderna» en TeatrEsco, n. ${ }^{\circ}$ 4, 2010-2011, 61 páginas.

3. Solo como ejemplo, su importancia en Nueva España como tipología festiva en Bravo ArRIAGA, M. D.: «Aspectos jocoserios de un mismo género dramático: máscaras serias y máscaras facetas» en FARRÉ, J. (ed.): Dramaturgia y Espectáculo Teatral en la época de los Austrias, Madrid: Iberoamericana, 2009, pp. 47-70.

4. Bolaños Donoso, P.: «La religiosidad popular sevillana en su literatura. (Lope de Vega y su teatro)» en Hurtado SÁnchez, J. (ed.): Religiosidad popular sevillana. Sevilla: Ayuntamiento de Sevilla. Univer- 


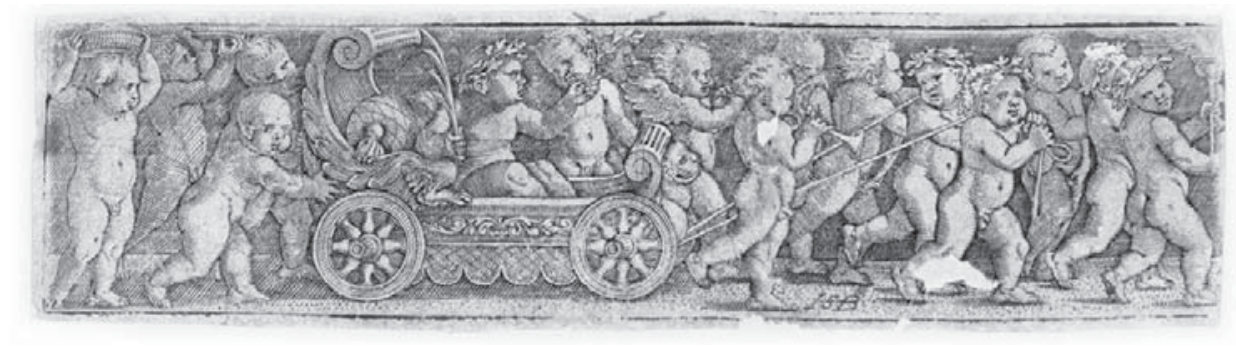

Fig. 1. Hans Sebald Beham. El carro del triunfo. (Circa 1531) Grabado calcográfico. Biblioteca Nacional

dad entre el público, en especial durante la representación de los entremeses, suponía un elemento sobresaliente de una festividad ya de por sí la más famosa entre las celebradas durante el calendario litúrgico en la ciudad de Sevilla.

Junto a esta línea antecedente de las mascaradas en la tradición festiva local, debemos considerar el papel que los triunfos de la Antigüedad tienen como inspiración para las mascaradas. La antigua celebración de la victoria guerrera entre los romanos se reintroduce en el mundo del Renacimiento a través de la literatura, la imagen y la fiesta, repleta de nuevas significaciones mediante el prestigio de lo clásico, y el uso de la alegoría. Sin duda un papel visual importante lo tuvieron los grabados de Durero o de Albrecht Altdorfer sobre el triunfo de Maximiliano I, con repercusiones pictóricas en nuestro país. La conformación de un espectáculo cortesano hispánico sobre la base del triunfo coetáneo europeo será más tarde una realidad en la España de los Austrias. ${ }^{5}$ Desde el punto de vista literario, y bajo el aura de prestigio itálico, es imprescindible considerar el papel de la obra de Petrarca en la conformación de una imagen de la fiesta del triunfo como espectáculo donde se unen la finalidad exaltativa, el sentido alegórico y el carácter procesional del espectáculo. En Sevilla, centro impresor relevante, se hace en 1526 una edición de los Trimphi... de Petrarca que había traducido al castellano Antonio de Obregón, con las correspondientes ilustraciones de sus alegorías. ${ }^{6}$

Otro papel fundamental es el de los eruditos, como Pedro Mexia, del que Lleó Cañal señalaba la presencia entre sus escritos de un capítulo dedicado al origen de los triunfos en la Antigüedad en su Silva de Varia Lección. ${ }^{7}$ De

sidad de Sevilla, 2000, pp. 63-96; SAnZ, M. ${ }^{a}$ J.: «El Corpus en Sevilla a mediados del siglo Xvi. Castillos y danzas» en Laboratorio de Arte, 10, 1997, pp. 123-137.

5. Chiva Beltrán, J.: «Triunfos de la Casa de Austria: Entradas reales en la Corte de Madrid», en Potestas, 4, 2011, pp. 211-228.

6. Cfr. A. de Obregón: Francisco Petrarca, con los seys triunfos de toscano sacados en castellano, con el comento que sobrellos se hizo, (edición crítica de Roxana Recio. eHumanista, 2012) http://www.ehumanista. ucsb.edu/projects/Monographs\%202/mongraphs/Recio.pdf. consulta 05/04/2012. Vid. López MÁrQUEZ, A. M.: «Historia de las traducciones españolas de los Triumphi de tetrarca (siglos xVI-xx)» en AdVersus, VII, 19-20, diciembre 2010-julio 2011, pp. 93-119.

7. En «La imagen del Emperador en la Sevilla del `500» en Moreno Mendoza, A. (ed.) Orto Hispalensis. Arte y cultura en la Sevilla del Emperador. Sevilla, Ayuntamiento, 2001, pp. 11-16. 
este modo, imágenes y palabras conformaron una atmósfera favorable a la recreación, adaptada a la peculiaridad local, de los cortejos triunfales desde la perspectiva de la imitación de los clásicos.

En Sevilla las máscaras se constatan como modalidad autónoma de festejo en el siglo XVI. Las primeras conocidas corresponden a las que se organizaron en 1559 con motivo de la paz con Francia, y posteriormente, destacan durante la segunda mitad del siglo las realizadas para festejar la victoria de Lepanto y el nacimiento del príncipe Fernando de Austria en 1571 y $1572 .{ }^{8}$

En realidad, sobre la fiesta de la mascarada sevillana se proyectan dos fiestas análogas en la idea del cortejo en movimiento, pero distintas en concepto y cada vez más a lo largo del Barroco, en forma: la máscara-paseo, de carácter nobiliario, y la máscara jocosa, unida indisolublemente al disfraz.

La primera, de carácter serio y majestuoso, se organizaba en virtud de acontecimientos regios o bélicos; la menor potencia de su impedimenta hacía posible que en ocasiones tuviera un carácter casi espontáneo. En ella se exhibían actitudes asociadas fundamentalmente a la aristocracia, como el lujo de la vestimenta empleada y el dominio del caballo; el paseo se efectuaba de noche, presidido por alguna figura principal de la ciudad o el propio asistente, y se iluminaba con hachas de cera. A este tipo de mascarada parece referirse el Diccionario de autoridades cuando define la fiesta como «Festejo de Nobles a caballo con invención de vestidos y libreas, que se executa de noche con hachas, corriendo parejas». ${ }^{9}$ En Sevilla, salvo algún ejemplo aislado posterior, se organizaron paseos de este tipo durante el siglo XVII, y hasta los comienzos del xviII. En 1624, con motivo de la estancia del rey en la ciudad, formaron en la plaza del Alcázar y salieron por la ciudad cincuenta parejas de jinetes, todos «caballeros y títulos», vestidos con ricas galas. ${ }^{10}$

En 1638, con motivo de la victoria de Fuenterrabía sobre los franceses, el paseo fue presidido por el conde de Salvatierra, a la sazón en el gobierno de la ciudad, y en 1704 la victoria del conde de Tolosa fue celebrada de similar manera. ${ }^{11}$

Durante el siglo XviII tales paseos disminuyeron, aunque perduraron asociados a las demostraciones de cañas y toros, como un apartado previo al desarrollo de estos espectáculos, quizás con la asimilación del contexto de las fiestas francesas y de la mascarada propiamente dicha, como cuando en mayo

8. Cfr. Ramos Sosa, R.: «Fiestas sevillanas del siglo xvi. Diversiones aristocráticas y regocijos populares», en Laboratorio de Arte, 7 (1994), pp. 41-50.

9. Citado por Bernal Martín, M.: «Algunas máscaras jesuitas del Siglo de Oro» TeatrEsco. Revista del Antiguo teatro Escolar hispánico, n. ${ }^{\circ} 1$ (2005-2006) 52 páginas. http://parnaseo.uv.es/ars/teatresco/revista/ Revista1/Revista1.htm. La diversidad tipológica de la máscara sevillana ya señalada por GARCíA BERNAL, J. J.: «Lo serio y lo burlesco: la máscara barroca como forma de pedagogía popular» en Demófilo, n. ${ }^{\circ} 18$ (1996), pp. 31-47.

10. Alenda Y Mira, J.: Relación de solemnidades y fiestas públicas en España. Madrid: Sucesores de Rivadeneyra, 1903, volumen I, 846.

11. Alenda, Loc. Cit, 1020; la noticia de 1704 en Matute Y Gaviria, J.: Anales Eclesiásticos y Seculares de la Ciudad de Sevilla. Sevilla, Imp. De Rasco, 1887, (Sevilla: Guadalquivir, 1997), tomo I, 32. 
de 1731 los maestrantes mostraron al público sus habilidades hípicas, vestidos con diferentes colores o incluso con disfraces a lo turco o a lo romano, en el ambiente ocioso de «óperas de música, bailes y otros festejos» que marcaban esos días de la presencia de la corte en la ciudad. ${ }^{12}$

En cuanto a la segunda acepción de la mascarada, será la influencia del mundo jocoso e irónico de la fiesta popular el que influirá fundamentalmente para su advenimiento. En este caso, la definición que de mascarada ofrece el diccionario de Covarrubias se acerca más a esta segunda variante «La invención que se saca en algún regozijo, festín o sarao de cavalleros o personas que se disfraçan con máscaras». ${ }^{13}$ Vemos en la mascarada la continuidad con los contenidos festivos que se propiciaron en las fiestas de los Inocentes, o que se incorporaron a la celebración del Corpus en la ciudad.

Durante el Barroco ambos perfiles de la fiesta se reunirán en un espectáculo donde confluirán las opciones por lo popular con la mencionada reflexión clasicista sobre el triunfo clásico y su reelaboración petrarquista, así como el conocimiento de la mascarada francesa.

Todavía se puede rastrear en la mascarada ya plenamente desarrollada del siglo Xviı atisbos de esa doble naturaleza, como por ejemplo en la Fábula de Hércules de 1707, donde el último carro del cortejo, denominado el real, era acompañado por un cortejo de caballeros emparejados y vestidos a la manera francesa y española, al modo solemne de la máscara paseo. ${ }^{14}$

Pero estos caracteres o modos -heroico y majestuoso, jocoso y lúdicoquedarán definitivamente unidos en la mascarada barroca, de modo que el epíteto asimilado al título de la fiesta era «jocoseria»; esta característica de su doble naturaleza es propia de la fiesta del Barroco, y explica su éxito, del mismo modo que se observa en otras festividades de la ciudad, en especial en la procesión del Corpus, con el conjunto de elementos procedentes del ámbito de lo popular y de lo litúrgico. Veremos que, como ocurriría con la fiesta eucarística, existirá una continuada tensión entre ambos, conflicto que terminará por plasmarse en la reforma de la fiesta en los tiempos de la Ilustración. Pero indiquemos ahora que, para su desarrollo parateatral, la sucesión de aspectos serios con otros de menor relieve propiciará el descanso del espectador en la captación de la analogía propuesta, y la suavización del mensaje,$^{15}$ aquella que permitía precisamente la asimilación de los contenidos, y que obtendrá los mejores beneficios en la aceptación del elogio del beato, del santo, el héroe o el rey. La dualidad expuesta de elementos cultos y populares de la mascarada se une al proceso de adopción de elementos procedentes de géneros diversos, y que terminarán por convertir a la máscara en una especie de paradigma de la síntesis de elementos que caracterizará a las artes del Barroco.

12. Matute, Anales, tomo I, 1731, 1.

13. Citado por Bernal MARTín, M., «Algunas máscaras».

14. Alenda Y Mira: Relación de solemnidades, I, 1668.

15. Cfr. Palacios, E.: El teatro popular español del siglo XVIII. Lleida: Milenio, 1998. 


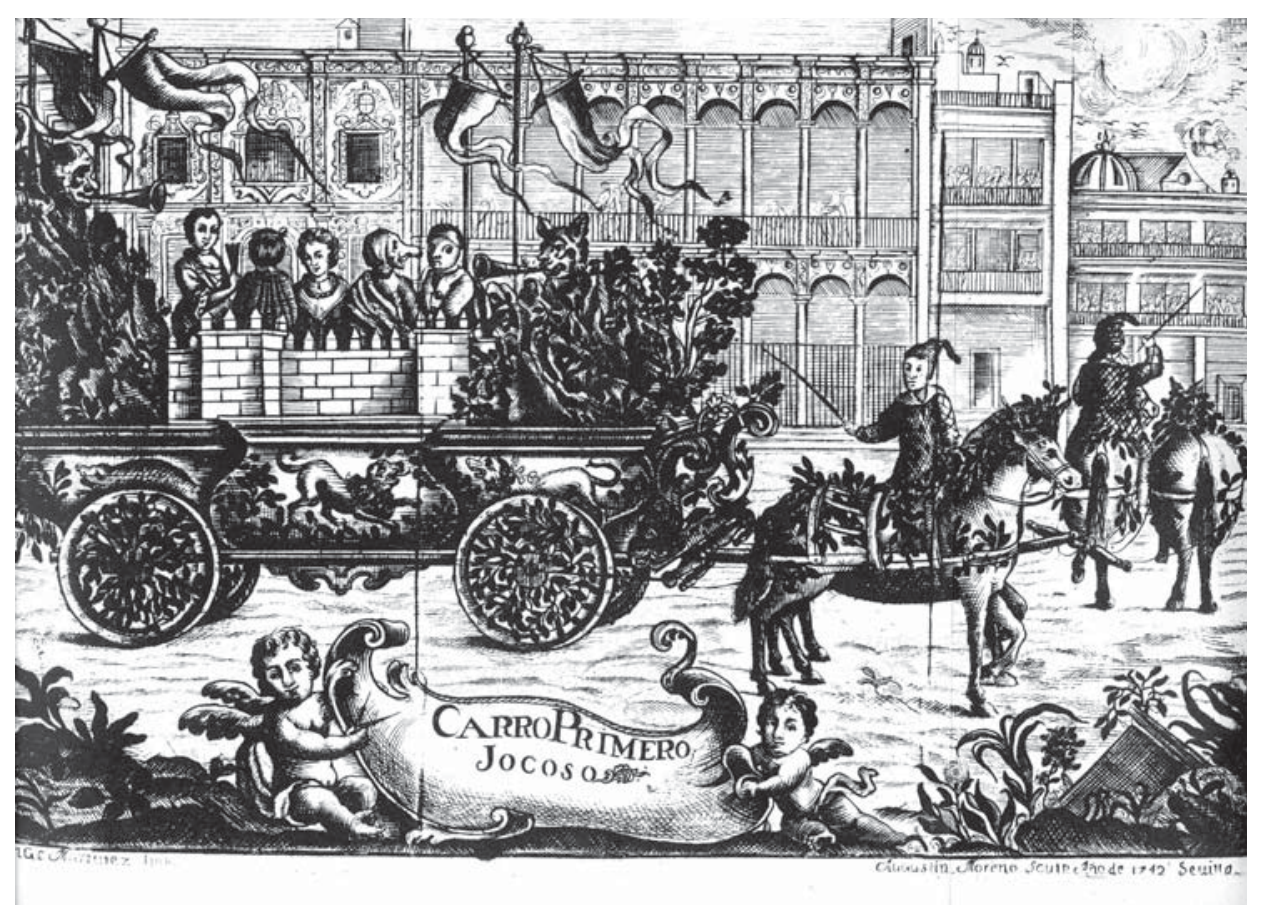

Fig. 2. Agustín Moreno bajo invención de Domingo Martinez. Carro primero jocoso. Cobre y talla dulce. Ilustración de la relación Aplauso real... de 1742

\section{Caracteres}

Durante el siglo XVII, las mascaradas jocoserias estaban formadas por cuadrillas con temas alegóricos o históricos, formadas por participantes a pie o a caballo, culminado en ocasiones mediante un carro triunfal que concluía la secuencia de los contenidos de la máscara. En el siglo xviı el paso de la mascarada se hace más complejo, siendo habitual que las cuadrillas se acompañen con diálogos dramáticos, mientras que como motivo central y sobresaliente de las distintas partes de la mascarada se utilizan distintos carros ornamentados. ${ }^{16}$

Para ese momento de madurez de la celebración, la máscara «debía, según costumbre, divertir al pueblo tres días» es decir, ${ }^{17}$ debía contener tres actos, situados en momentos o fechas diversas: el primero de ellos era el pregón o

16. Cfr. GarCía Bernal, J. J.: «Fisiognómica y código estético de las mascaradas públicas del barroco hispano: crítica y evolución del concepto de la «máscara jocoseria» en Actas del Congreso Internacional de Imagen y apariencia. Murcia: Universidad de Murcia, 2008. http://congresos.um.es/imagenyapariencia/ imagenyapariencia2008, Consulta 10/01/2012.

17. Trigueros, C. M.a: Relación de las fiestas, regocijos, i limosnas que celebraron, prepararon, y repartieron los Diez Gremios maiores de la ciudad de Sevilla, con motivo de la ratificación de la paz, i del venturoso nacimiento de los serenísimos infantes gemelos Don Carlos, i Don Felipe, augustos nietos del Rey, Sevilla: Oficina de Don Manuel Nicolás Vázquez y Compañía, 1784, cita de pág. 8. 
publicación, donde se daba noticia pública de la celebración particular, y que solía ser un cortejo más breve, formado al menos por una cuadrilla que servía para la difusión pública del espectáculo; el pregón tenía un carácter casi siempre cómico o jocoso, para llamar la atención sobre la fiesta, y no era extraño que parodiase el anuncio de fiestas reales o solemnes que solían realizar el cabildo u otras instituciones de la ciudad. Con posterioridad a este anuncio discurría la mascarada propiamente dicha, compuesta por carros y cuadrillas, que suponía el eje central de la mascarada; finalizada esta, se culminaba su acontecer con un víctor formado por alguno de los carros que habían participado en la misma, articulado en torno al pretexto de una regalo o una cesión material: una cartela decorada en el caso de la mascarada de la Real Fábrica de Tabacos de 1747, aunque con el añadido del regalo a los capitulares de los retratos de los reyes, o un lienzo con inscripciones, en el caso de la organizada por los Diez Gremios en 1784, ideada por Cándido María Trigueros.

Pero toda la mascarada iba a adquirir, fundamentalmente en el siglo XviII, un sentido último, una referencia en torno a un tema elogioso o de exaltación, presentado mediante el uso de una alegoría de carácter genérico, que explicaban tanto la decoración, el sentido y los personajes de los carros como los que componían el resto del cortejo. Para ello se servirán de los ejemplos proporcionados por la historia bíblica y la Antigüedad, la mitología grecolatina, y además, el conocimiento de la sociedad coetánea, la cercana y la alejada en el tiempo o en el espacio -incluyendo salvajes, turcos o indios--, de acuerdo a una multiplicidad de significados y relaciones que, estando insertas en el tema global que titula la mascarada, desarrollan la misión de incluir en la representación una imagen general del mundo, un universo tan amplio que sustente, en definitiva, mediante la generalización ad populum, la idea que da origen al cortejo. Esta diversidad en procesión de la mascarada discurre así en correspondencia con una visión más globalizada de la geografía del planeta, mirada característica del siglo, así como con la ilusión de dominio -o de control- que la presencia de sus diferentes figuraciones conduce tanto al que organiza como al que observa el espectáculo.

De ahí el mundo abreviado con que se titula alguno de los más afamados ejemplos de máscara dieciochesca, la que en 1747 recorrió las calles de la ciudad desde la Real Fábrica de Tabacos en la collación de San Pedro, ${ }^{18}$ o el que las máscaras se pregonen a todo el mundo en general, tanto a «Cavallos, los Borricos, y los Mulos /, los Persas, losAbisinos / los Babilonios, y Turcos / y quantos aran y caban /en los campos mas incultos /del África, y de Xerez». ${ }^{19}$

18. Pizarro Gómez, F. J. y Viña Díaz, S.: «La Máscara del mundo abreviado de Sevilla. Iconografía y emblemática en la fiesta urbana del siglo XVIII» en Margarita Torrione (Ed.) España festejante. El siglo XVIII. Málaga: Diputación, 2000, pp. 477-493; sobre esta máscara, véase Alfredo José MorALES MARTíNEZ: «Imagen urbana y fiesta pública en Sevilla: la exaltación al trono de Fernando VI», en Reales Sitios: Revista del Patrimonio Nacional, 165, 2005, pp. 2-21.

19. Alenda: Relación de solemnidades, tomo I, 1668, sobre mascarada por la celebración del nacimiento del futuro Luis I en 1707. 
El carácter universal de la «fábula» representada, además de acentuar el valor del elogio, permitía lograr la opinión, si no favorable si aquiescente, del conjunto de la población sobre el tono de su exposición, donde por encima de la burla o la ironía desplegada, su pensamiento fuera «aprobado en todo de todos». ${ }^{20}$

El mundo de apariencia de la máscara tendrá en el ornato una alianza fundamental: desde la colgaduras y telas de calles y balcones, adorno que solicita la máscara habitualmente a través de su pregón, y que en ocasiones contará con el apoyo mediante multas a los vecinos remisos por parte del cabildo, hasta estructuras efímeras más complejas como fachadas arquitectónicas y arcos. En realidad, la mayor parte de las ocasiones estas estructuras servían para adornar el circuito de todo el acontecimiento festivo y por tanto de las actividades paralelas a la organización de la mascarada, pero en este contexto eran también jalones ornamentales de su paso por su itinerario ciudadano, como en 1742 con motivo de la entrada del cardenal Borbón en la ciudad, donde se erigieron dos arcos, en la entrada de la calle de la Mar y antes del palacio de los arzobispos, o el que en 1784 estaba aún inacabado en la plaza de San Francisco para el cortejo de la mascarada que celebró el nacimiento de los infantes y la paz con Gran Bretaña. ${ }^{21}$ Junto al ornato externo, hay que considerar el propio adorno de los carros, con el uso de telas y pinturas que recrean colores, figuras, con paisajes o vistas de la propia ciudad de Sevilla, conforme a la tradicional complacencia de la fiesta barroca hispalense. El mensaje transmitido es complejo y no será fácil de articular para el espectador, conforme a la idea desarrollada anteriormente del término de su entendimiento a través de la memoria escrita de la fiesta. La composición de analogías con personificaciones y temas bíblicos, doctrinarios y mitológicos se unirá a una emblemática creada al efecto, sostenida por motes, lírica y letreros.

El ambiente que propiciará la creencia de esta generalización del mensaje tendrá como característica formal común el disfraz: máscara que garantiza la figuración del personaje social, histórico o mitológico, pero también la liberalidad del común acuerdo, la conversión en un súbdito tipo que expone como cualquier otro la fe en el mensaje y de este modo la verosimilitud del mundo creado. El sentido general de la fábula o representación se distribuye en agrupaciones o cuadrillas, alrededor de carros que justifican su agrupación mediante un pensamiento particular y subordinado al fin último. En las cuadrillas cabe una mayor variedad, que permiten una red de variaciones y juegos más

20. Alenda: Relación de solemnidades, tomo I, 684, de la máscara inmaculista de cirujanos y barberos de 1617.

21. Relación universal de las festivas demonstraciones que se han hecho en la muy noble y muy leal ciudad de Sevilla para celebrar el solemne triduo de la possessión que por el sereníssimo señor Infante Cardenal Luis Antonio Jayme de Borbón... Sevilla: Antonio de Espinosa, 1742, pp. 15 y ss, y Trigueros, C. M.a: Relación de las fiestas, regocijos, i limosnas que celebraron, prepararon, y repartieron los Diez Gremios maiores de la ciudad de Sevilla, con motivo de la ratificación de la paz, i del venturoso nacimiento de los serenísimos infantes gemelos Don Carlos, i Don Felipe, augustos nietos del Rey... Sevilla: Oficina de Don Manuel Nicolás Vázquez y Compañía, 1784, pp. 31 y 32. 
alejados, con referencias muy amplias: el repertorio jocoso incluye la gala y la asimilación de aquello que configura la propia ceremonia. Así, se construyen así figurada milicia -como la de la Fábula de Teseo, de 1742, en donde un niño capitanea la fingida tropa-, o se produce la burla de aquellos que componen el protocolo y la ceremonia de la fiesta, como los alguaciles, «ridículos a caballo, aplaudida por lo extraordinario de sus disfraces, y por el afectado señorío, con que se portaron». ${ }^{22}$ Pero incluso en los carros burlescos o jocosos la representación gira o debe girar en torno a la idea representada.

\section{RECORRIDOS}

Este mundo extenso y diverso que propicia la creación festiva de la mascarada también tendrá sentido en un amplio recorrido por las calles y plazas de la ciudad. Los caminos elegidos a través del municipio serán muy diferentes, determinados por la situación urbana de la corporación, colegio o entidad que lo patrocina. Su itinerario enseguida buscará las calles reales o las vías principales más cercanas al punto de partida, y su paso posterior por la trama urbana que la reiteración de celebraciones habían convertido ya en un eje festivo tópico de la ciudad. Un recorrido que ejercerá siempre su atracción sería el determinado por las vías de la llamada estación del Corpus, que tenía en la calle de las Sierpes, la plaza de San Francisco y la calle Génova en su continuación hacia la catedral una ruta ampliamente concurrida en su camino urbano.

El paso de las principales mascaradas incluía lugares especialmente significativos que se convertían en escenarios específicos para la recreación ante el público más selecto de los significados y representaciones que condensaban estos cortejos. Un espacio fundamental sería la plaza de San Francisco, sede de la justicia y el gobierno de la ciudad. En aquellas mascaradas más relacionadas en su contenido con el poder real, y dado que la representación de la monarquía correspondía a la autoridad máxima sobre el cabildo, quién usualmente invitaba a la participación de las instituciones que tomaban el encargo de realizar las mascaradas, el término de la misma o una importante estación se efectuaba frente a las Casas Capitulares. Así ocurrió en el caso de la fiesta de este tipo patrocinada por la Real Fábrica de Tabacos en 1747, cuando se hizo entrega, en el víctor que cerraba tales actos, los retratos reales pintados por Juan de Espinal a la corporación municipal; en otros casos, el lugar central de la plaza, su capacidad para contener un público amplio y su importancia representativa hacían que se convirtiese en paso obligado para los carros. Así sucede en las mascaradas organizadas por el Colegio de San Hermenegildo y el de Santo Tomás en 1742, con motivo de la toma de posesión del infante cardenal don Luis de Borbón.

22. Relación universal... 1742, 86 y ss. 
En ocasiones, como en la de la mascarada organizada por la universidad literaria en 1789 con motivo de la proclamación del rey Carlos IV, llamada $E l$ triunfo de la sabiduría sobre el error, el paso por una plaza de San Francisco poblada de público se acompañó de las danzas de los estudiantes sobre el tablado que soportó la ceremonia de la proclamación real, siendo presenciada la celebración por el cabildo de la ciudad desde sus Casas Capitulares y por los miembros de la Real Audiencia, acompañados del juez conservador de la universidad, desde el balcón principal de esta institución. ${ }^{23}$ El entorno de la catedral y el palacio arzobispal aparecen como una referencia urbana de sus trayectos, en especial -como es lógico-, con los acontecimientos relacionados con la clerecía o la mitra hispalense. Así sucedió en las referidas máscaras organizadas en la recepción sevillana de 1742, cuando las máscaras entraron incluso en los patios de palacio y serpentearon por las calles repletas de público hasta las actuaciones previstas en el palenque anejo a la residencia arzobispal.

\section{MASCARADA Y COMEDIA}

La mascarada, donde prima en gran medida lo parateatral, se encuadra en un grupo de representaciones de complejo encuadre, junto a coloquios y zarzuelas, vejámenes académicos y universitarios, y otras fiestas en colegios y conventos. En la capital sureña, y en una etapa marcada por la prohibición de la actividad teatral en la ciudad, desde al menos la desaparición del teatro de la Montería a fines del siglo XVII hasta la apertura en la época ilustrada, se ofrecía la mascarada como una posibilidad de hacer teatro "como en tablas». ${ }^{24} \mathrm{Sin}$ duda, la asimilación de los contenidos del espectáculo, sujeto a la adquisición paulatina que el cortejo móvil determinaba, se acentuaba con los núcleos de contenidos que desarrollaban cuadrillas y carros, y sus insertos jocosos en correspondencia a la intervención de los graciosos o las interrupciones de los sainetes. Los propios carros se componían a modo de escenas teatrales, concebidas en un fingido espacio o entorno, con figuras caracterizadas por su gesto y vestuario. En la sucesión de cuadrillas y carros existía una formulación retórica vinculada a la formación intelectual de los autores de estos cortejos, como luego veremos, basada en la progresión de las analogías sucesivas y su relación con el mensaje final de la máscara. Sin embargo, también se ha señalado cómo en la mascarada el hilo del desarrollo dramático se disolvía en la articulación tan diversa de esta tipología festiva, donde se sucedían disfraces,

23. Su relación fue estudiada y transcrita por Ruiz LAgos, M.: Cultura simbólica e ilustración andaluza. Jerez de la Frontera (Cádiz): Centro de Estudios Históricos Jerezanos, CSIC, 1985, p. 188. Ver también MATUte: Anales, III, 1789, p. 97.

24. Cfr. Bolaños Donoso, P. y de los Reyes Peña, M. en su estudio introductorio a Una mascarada Joco-Seria en la Sevilla de 1742. Sevilla: Universidad de Sevilla, 1992. Sobre la variedad terminológica referida, aplicada en su caso a la comedia jesuítica, Menéndez PELÁEz, J.: «La comedia jesuítica del XVII» en Arellano, I. (coord.): Paraninfos, segundones y epígonos de la comedia del Siglo de Oro, Barcelona, Anthropos, 2004, pp. 11-20. 
poemas, danzas, letras cantadas, y sobre todo, loas o piezas dramáticas insertas en el cortejo y declamadas desde los carros o por las cuadrillas.

Conocemos cómo estas representaciones dramáticas ocuparon en muchas ocasiones un papel preeminente en la fiesta, comportándose, si no de un modo independiente al cortejo, si con un sentido autónomo. La máscara acaba o se para a veces en un escenario, como el palenque instalado junto al palacio arzobispal en 1742 para el desarrollo del diálogo; ${ }^{25}$ en otras ocasiones, la loa o la comedia suscita el interés particular del público, como en la proclamación de Carlos IV en 1789, cuando se solicitó que la máscara del colegio de Santo Tomás repitiera para el ayuntamiento la representación teatral en las galerías de las casas consistoriales. ${ }^{26}$ Pero, en realidad, el cumplimiento de su mensaje no acababa con el fin del itinerario de la mascarada, sino que terminaba con la narración escrita de su orden y explicación de contenidos en las Relaciones, los textos «después» de la fiesta que indicaba Díez Borque y que suponían no solo la perduración para la posteridad del esfuerzo festivo o la constatación de la importancia del instituto o corporación patrocinadora, ${ }^{27}$ sino también la definición y comprensión final de los conceptos y metáforas propuestas en la fiesta.

\section{LOS CONTENIDOS. LA ALEGORÍA MITOLÓGICA}

De acuerdo con el contexto de la cultura clasicista donde se inscribe, la mascarada tendrá su tópica inspiración en el triunfo romano, que tiene en común con la fiesta barroca la exaltación de un personaje y la movilidad del cortejo en un espacio urbano. En el caso de la mascarada, la conexión con la fiesta de la Antigüedad se realiza a través de la visión de Ovidio y el tema triunfal divulgado por el Renacimiento mediante las ediciones mencionadas de la obra de Petrarca. Con sus enseñanzas, la mascarada adquiere la capacidad alegórica y el entendimiento del festejo como el elogio de la virtud heroica y moral, de modo que el personaje -santo, monarca o miembro de la familia real- que se exalta se convierte en dechado de atributos mediante la identificación con los personajes clásicos o mitológicos que se representan.

La elaboración del festejo se vuelve paulatinamente más erudita y guarecida bajo el tema o fábula alegórica. Así se entiende por los que auspician la fiesta, -como por ejemplo, el propio cabildo civil- cuando solicita en 1742 con motivo del nombramiento como arzobispo de Sevilla del infante cardenal Luis de Borbón que durante el triduo festivo por este suceso «con pensamientos eruditos e ideas literarias amenasen (amenizen) las máscaras». ${ }^{28}$

25. Relación Universal, 1742, 151.

26. Matute: Anales, III, 1789, 98.

27. Como señala en distintas publicaciones, como Díez Borque, J. M. ${ }^{a}$ : «Los textos de la fiesta: ritualizaciones celebrativas de la relación del juego de cañas» en CoRdobA, P. Y ÊTIENVRE, J. P. (comp.) La fiesta, la ceremonia, el rito. Madrid: Casa de Velázquez, Universidad de Granada, 1990, pp. 181-193.

28. Relación universal, p. 86 y ss. 
Esta mirada hacia la Antigüedad clásica durante el barroco sevillano no estaba exenta de problemas. Una vez pasados los tiempos de la concordia entre mitología y fe que propiciara el Renacimiento en los círculos eruditos de la ciudad, y dada la importancia de la metáfora que se sugería en la fiesta como recurso retórico, su uso debía quedar sometido a las particularidades de la identificación. El autor de la Relación universal... defenderá esta apropiación de lo mitológico, porque «Bien podemos, pues, tomar bosquexos, y sombras de la virtud, dé la sabiduría prophana, á imitación de San Basilio...». ${ }^{29}$ Referencias a bosquejos y sombras que aluden al carácter distante sobre el ideal, al modo platónico, con que pueden los mitos clásicos reflejar el conocimiento que definitivamente quedará expresado a través del cristianismo. Precisamente esta «sabiduría profana» está defendida por el autor, utilizando para ello el hecho de que se utilizaran en las Sagradas Escrituras, indicando las Epístolas de san Pablo como lugar donde se emplean estas referencias paganas. Pero también menciona otras vías de penetración del clasicismo en su entorno cultural inmediato, como el caso de la escena dramática de comedias y zarzuelas, tal como habían realizado Lope de Vega, Calderón de la Barca y otros autores en el espectáculo hispano. Esta última forma de inmersión suponía en lo mitológico un aprendizaje en su uso en la escena y la literatura afín al procedimiento creativo de la mascarada barroca. Con ello, también una manera de situar al público en el conocimiento del mito clásico como inventio pero también como recurso estilístico vinculado a la elocutio, como posible objeto del juego retórico en la máscara jocosa. ${ }^{30}$

Por último, la relación hace uso de la que sería otra importante fuente de referencias de lo clásico, como era la de la propia literatura de festejos contemporáneos, reforzada su misión descriptiva de la fiesta y su ornato con las imágenes visuales aportadas en muchas de estas ediciones. De manera directa se alude a los usos alegóricos de la mitología en la entrada en Amberes del infante cardenal don Fernando cuyo conocimiento debió ser propiciado por la lectura de la conocida Pompa Introitus Honori Serenissimi Principis Ferdinandi Austriaci... de Gevaerts, con ilustraciones de Rubens. ${ }^{31}$

Esta invención alegórica debía estar sometida a diferentes consideraciones, aquellas determinada por el «bien hablar» de la retórica trasferido al campo de la fiesta y su recorrido visual. La justificación de la mascarada jocoseria tenía su base intelectual en Aristóteles, y se sostenía en el contexto barroco a través de autores como Enmanuele Tesauro: el complemento de la seriedad

29. Relación universal, 95.

30. CRISTÓBAL, V.: «Mitología clásica en la literatura española: consideraciones generales y bibliografía» en Cuadernos de Filología Clásica y Estudios Latinos, 18, 2000, 29-76.

31. Gevaerts, Jean Gaspard: Pompa introitus honori Serenissimi Principis Ferdinandi Austriaci Hispaniarum Infantis S.R.E. Card Belgarum et Burgundionum gubernatoris... a S.P.Q. Antuerp. decreta et adornata..., Amberes, 1641). En la Relación universal se cita en concreto las metáforas del arco triunfal junto al convento de San Miguel, donde se encontraba el palacio, con la opción de Hércules por el camino de la virtud, enseñado por Minerva, frente a Baco, Venus y Cupido, así como la obtención de la cimera por Belorofonte. 
del mensaje sería la chanza, entendida como una capacidad para flexibilizar el discurso y hacerlo más digerible; su aparición permitía poner en marcha la inteligencia del espectador, y daba lustre al contexto del discurso, para una mejor asimilación del concepto. Se trataba de una delicada situación intermedia entre la escurrilidad, el exceso de jocosidad que convertía la broma en un fin en sí mismo, y la rusticidad, o ausencia de comicidad que conllevaba a una incapacidad para el ejercicio retórico. ${ }^{32}$ En realidad, lo jocoso se convertía en un instrumento extremado de la finalidad del discurso literario del texto barroco o del espectáculo de la mascarada, puesto que, bajo su disfraz de burla se destilaba la verdad, entendida finalmente como una enseñanza moral, un auténtico «sermón estoico, vestido de máscaras placenteras», como indicaba Quevedo. ${ }^{33}$ Como veremos, esta misión se convertirá en el pretexto intelectual de la capacidad comunicativa de los elementos cómicos y populares, que hacen posible en definitiva la conversión de este espectáculo en un acontecimiento de masas.

\section{FÁBULAS Y PERSONAJES}

Sin adentrarnos en un estudio exhaustivo sobre los aspectos variados de la iconografía y contenidos de la máscara sevillana, señalamos ahora algunos caracteres de su temática principal. Pese a la comentada dispersión que existe en esta tipología festiva, determinadas máscaras consiguen mantener un grado de cohesión mayor entre los diferentes temas y asuntos desplegados en carros y cuadrillas.

Entre los temas reiterados en las máscaras está la protección o la exaltación por parte de los saberes sobre el personaje al que está dedicada la fiesta. El patrocinio de los colegios docentes y la invención de la máscara por parte de alguno de sus profesores explica la presencia de estos contenidos, que suponen la participación en el cortejo de los dioses mitológicos patrones de las artes y las ciencias, (Apolo, Atenea...) y en general de la abundancia y la tierra, con Gea y Cibeles como protagonistas.

Se abunda habitualmente en la personificación de las disciplinas colegiales, que se convierten en cuadrillas sostenidas por la presencia de diferentes grupos de estudiantes y disfraces. Gramática, Poesía, Retórica, Astrología, Filosofía, Gramática, las Artes, Geometría, Matemática y Filosofía natural, la Medicina, la Jurisprudencia y la Teología aparecen comúnmente en la máscara, como

32. Así se justificaba en el impreso Carta del Doctor $D . N$ del $N$ vicario de la ciudad de $N$ en respuesta a las tres cartas de Garci Pérez de Navajas. 1 de enero de 1747. En Colección de pregones, cartas y folletos relativos a las fiestas celebradas en Sevilla con motivo de la proclamación del rey d. Fernando VI. 1747 Biblioteca Nacional, R/23380, pp. 175-185.

33. Citado en FASQuel, Samuel: «La enunciación paradójica y las estrategias del discurso burlesco» en Criticón, 100, 2007, pp. 41-57. El tema de la «antidignidad» del mito en la máscara sevillana ha sido destacado por GARCía Bernal, J. J.: «Lo serio y lo burlesco...». Véase también El fasto público en la España de los Austrias. Sevilla: Universidad de Sevilla, 2006. 


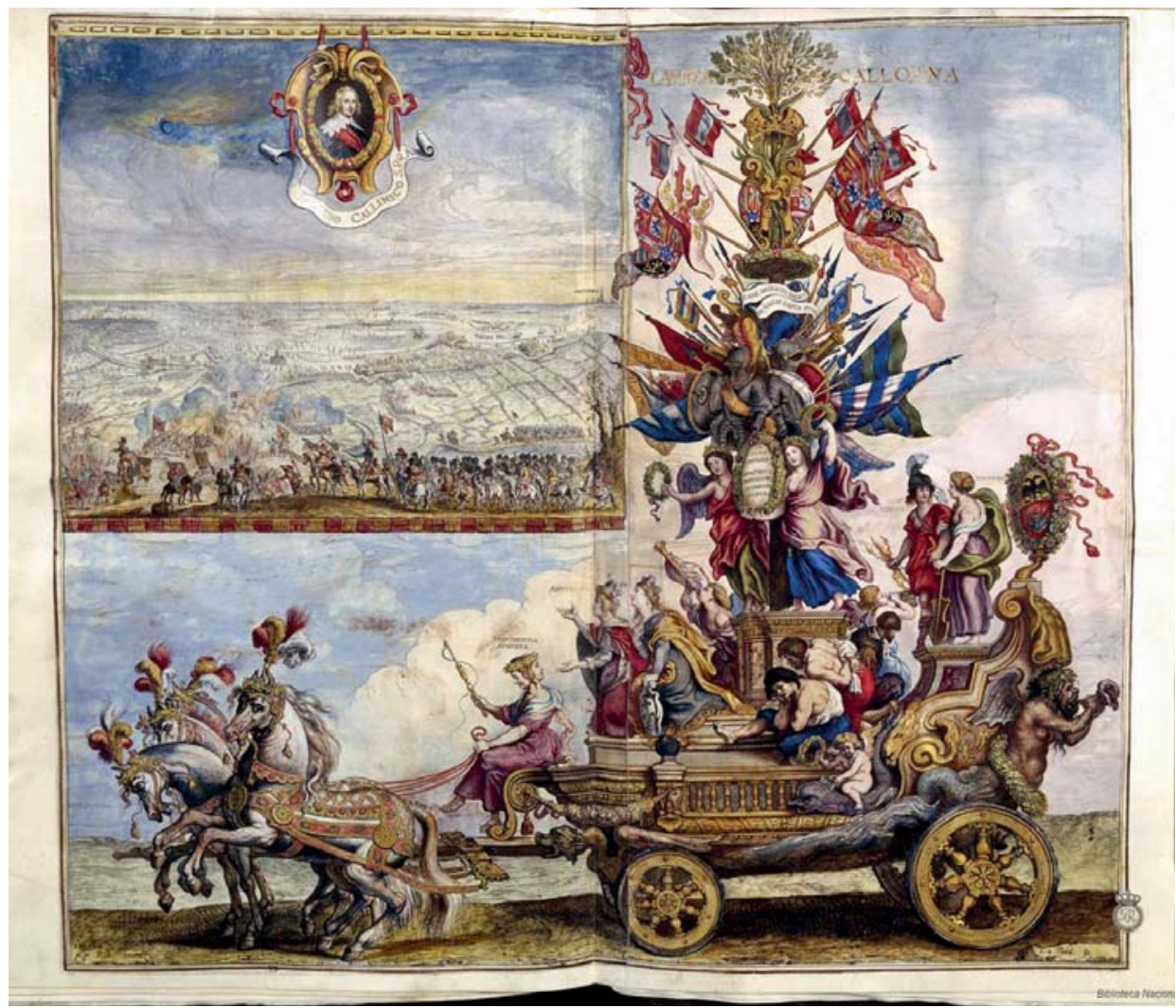

Fig. 3. Peter Paul Rubens y Theodoro A. Thulden. Laurea Calloana. Carro triunfal en honor del príncipe Fernando (1642). Ilustración al aguafuerte de Pompa Introitus...

lo hacen exaltando la tan sevillana creencia inmaculadista en la alegría por el breve pontificio en $1617^{34}$ o por la beatificación de Ignacio de Loyola en $1610 .^{35}$ En general se trata de un conjunto de materias relacionadas con la formación colegial de los principales centros docentes sevillanos, patrocinadores a su vez de importantes mascaradas; la capacidad para la conformación de espectáculos y textos dramáticos que estos colegios, especialmente de los jesuitas de San Hermenegildo, mantuvieron a través del teatro infantil y humanístico orientado a las enseñanzas de la Retórica o el Latín, serviría como experiencia para el uso de la metáfora clásica que abunda en la máscara. ${ }^{36}$

34. Sanz Serrano, M. ${ }^{a}$ Jesús: Fiestas sevillanas de la Inmaculada Concepción en el siglo XviI. El sentido de la celebración y su repercusión exterior. Sevilla: Ayuntamiento. ICAS, Universidad de Sevilla, 2008.

35. Martín, M. ${ }^{a}$ Bernal, «Algunas máscaras jesuitas del Siglo de Oro» TeatrEsco. Revista del Antiguo Teatro Escolar Hispánico n. 1 (2005-2006) en http://parnaseo.uv.es/Ars/TEATRESCO/Revista/Revista1/ Mascaras/Bernal.htm.

36. Véase, entre otros, Menéndez Peláez, J.: Los jesuitas y el teatro en el siglo de oro, Oviedo, Universidad, 1995. 
Un tema principal de la mascarada será, por supuesto, la exaltación del monarca, los príncipes y la familia real, que se relacionan con importantes relatos de la mitología y la literatura grecorromanas. El rey se convierte en un Eneas que visita a su padre Anquises en los campos elíseos para la máscara jesuita de 1729 en el recibimiento de Felipe V, dispuesto a la promesa ante su antecesor el rey san Fernando en la fértil Sevilla. ${ }^{37}$

El nacimiento de Luis de Borbón, futuro Luis I, fue celebrado con varias fiestas que generaron un amplio repertorio de relaciones. El futuro monarca se convierte en un nuevo Hércules, a tono con el conocido referente clásico de la monarquía hispana, pintado al comienzo de la relación que describe la mascarada de los jesuitas como un hispano león y un francés gallo, que comparten entre ambos «La gloria y el Interés». ${ }^{38}$ Otro Luis de Borbón, en este caso el infante convertido en arzobispo de la ciudad, es recibido en 1742 por la máscara del Colegio de San Hermenegildo como Teseo liberador de las artes y las ciencias colegiales de los errores y la ignorancia, y favorecedor del saber en la Atenas sevillana. ${ }^{39}$ El colegio volvería a hacer uso de un relato clásico, el del rey como Cadmo, fundador de Cadmea-Tebas, para la proclamación del monarca Fernando VI en $1747 .{ }^{40}$

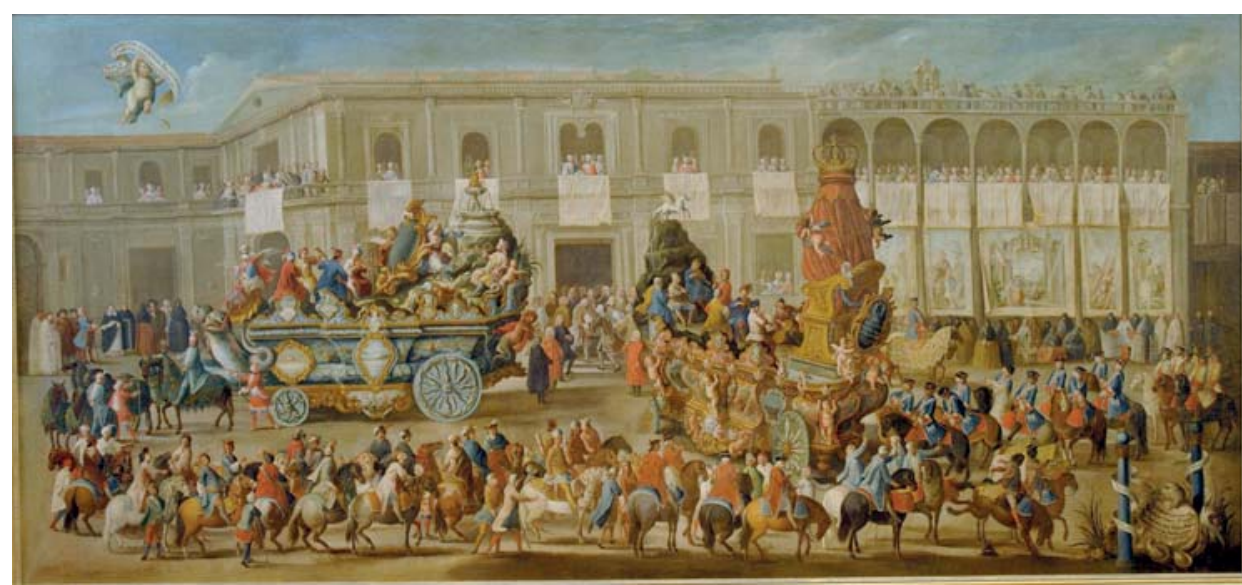

Fig. 4. Domingo Martinez y otros pintores de la ciudad. Carro del Parnaso y del Víctor. Óleo sobre lienzo. De la serie sobre la mascarada de la Real Fábrica de Tabacos de 1747. (Museo de Bellas Artes de Sevilla)

37. El piadoso Eneas de las Españas: solemne alegórica demonstración de regocijo, con que aplauden y celebran la feliz venida de los Reyes Católicos a esta muy Noble, y Leal Ciudad de Sevilla los maestros de sastrería residentes en la misma ciudad ... Sevilla : Viuda de Francisco Leefdael, 1729.

38. Fabula Heroyca: Hercules fundador de Sevilla : celebración festiva al felicissimo natal del Principe de las Asturias ... Luis I. Sevilla: Francisco De Leefdael, 1707, en el primer folio tras la dedicatoria.

39. Relación universal, 1742.

40. Matute, Anales... II, 1747, aunque la relación gira ya sobre la alegoríade Júpiter. Véase nota 90. 
Pero cada vez con mayor claridad en el siglo XviıI, la alegoría de la familia real se une al Olimpo de los dioses: si Luis de Borbón es Júpiter, el rey asume el papel de Titán al lado de la reina -Cibeles- representados con sus hijos Marte, Minerva, Apolo, Neptuno, Juno, Astrea y Mercurio, -la familia real, Roma y el cardenal Aquaviva - en el cortejo del Colegio dominico de Santo Tomás para esa recepción del nuevo arzobispo de sangre real. ${ }^{41}$ En el cortejo de 1747 organizado por la Real Fábrica de Tabacos, los reyes se sitúan en el Parnaso, junto al monte presidido por Apolo, a la popa del carro con sus reales retratos pintados por Juan de Espinal. ${ }^{42}$

A partir de la fiesta ideada por Cándido María Trigueros en 1784 para los Diez Gremios, se aprecia un cambio en la temática monárquica de las máscaras; la exaltación de la monarquía se efectúa en un contexto radicalmente clásico, con un matiz, si no arqueologizante, al menos pretendidamente cientifista, a través de la reproducción de un triunfo romano donde abundan las referencias latinas. En abril de 1789, y para la proclamación del nuevo rey Carlos IV, se crea por la Universidad una máscara denominada El triunfo de la sabiduría sobre el error, es evidente este cambio de tendencia en el elogio al monarca, convertido ya $-\mathrm{y}$ en paralelo a un cambio general en la fiesta de la ciudad-, en el benefactor del progreso humano por medio de las artes y las ciencias, concebida ahora de manera más moderna a través de su aplicación en la industria, la navegación, y otros saberes prácticos que redundan en la felicidad pública. ${ }^{43}$

\section{Conflictos y eVOlución}

El éxito y la popularidad de las mascaradas está en consonancia con el amplio abanico de entidades e instituciones de la ciudad que participarían en el patrocinio de esta fiesta. Entre las religiosas, lo fueron conventos como el de mercedarios (1617), o hermandades penitenciales como los Negritos (1675) o sacramentales como la del Sagrario (1683); la Real Maestranza, como corporación aristocrática, patrocinaría diferentes mascaradas paseo (1704, 1707, entre otras cabalgadas); fábricas reales como la de Tabacos (1747), o agrupaciones regionales como los asturianos (1707) o incluso legalmente marginadas como los gitanos (1747) acometerán la tarea de organizar estos cortejos. Pero sobre todo, serán las corporaciones laborales o gremios por una parte, y los colegios docentes por otra, los grandes patronos de las mascaradas sevillanas. Entre los primeros destacan los mercaderes como principales promotores $(1617,1729,1784)$ seguidos por los sastres $(1707,1729)$, pero lo

41. Aplauso Real, aclamación afectuosa y obsequio reverente, que en lucido Festejo de Mascara JocoSeria consagraron los escolásticos alumnos del Colegio Mayor de Santo Tomás... el día 2 de mayo de 1742... Sevilla: Imp de los Recientes, 1742. Ed. Facsímil en Una mascarada Joco-Seria en la Sevilla de 1742...

42. Cfr. Pizarro Gómez, F. J. y Viña Díaz, S.: «La Máscara del mundo abreviado» y Morales MARTínez, Alfredo J. : «Imagen urbana y fiesta pública en Sevilla».

43. Cfr. Ruiz Lagos, M.: Cultura simbólica e ilustración andaluza. 
serían igualmente cirujanos y barberos, gorreros, sederos, plateros, espaderos, o zapateros.

En cuanto a los colegios docentes, serán los más importantes en la docencia de la élite de la ciudad -Colegio Universidad de Santa María de Jesús, Colegio jesuita de San Hermenegildo y dominicos Santo Tomás- los grandes protagonistas en la elaboración de las mascaradas. Durante el siglo XVIII serán estos centros colegiales los que llevarán el peso en la elaboración de estos cortejos, tanto en el número de celebraciones como en su importancia cualitativa.

$\mathrm{Su}$ preponderancia progresiva supuso, desde el punto de vista de los contenidos expuestos en los cortejos, un mayor grado de intelectualización mediante la insistencia en la erudición literaria de los textos y la complejidad de las alegorías que se plantean en ellas. En la conformación del cortejo y sus contenidos tendría protagonismo el cuerpo docente de los profesores, mientras que en el desarrollo de la celebración propiamente dicha, formando parte del cortejo o del cuerpo de figurantes o actores participaban los propios estudiantes; es interesante destacar, como veremos más adelante, que una acusación habitual entre los centros contendientes por la gloria de tales fiestas era la participación a cambio de dinero de actores o compañías profesionales en el desarrollo de las mascaradas, lo que nos habla de que el espectáculo se había convertido para la fecha en un esfuerzo que superaba los límites del divertimento colegial.

Esta prevalencia en la organización de los festejos de los colegios docentes de la ciudad aceleraría la competencia entre los mismos, especialmente entre los colegios religiosos de jesuitas y dominicos, aquellos que pugnaban con la Universidad de Santa María de Jesús en el favor del alumnado sevillano y el otorgamiento de grados académicos, por la organización de las mejores mascaradas. Este enfrentamiento debe entenderse como un capítulo de la pugna a escala local entre los institutos religiosos más potentes de la Iglesia en su misión apostólica, que manifestaban con estos festejos su capacidad para movilizar a sus adeptos y devotos entre la élite social de la ciudad.

La competición entre los centros docentes debió aumentar con motivo del encargo común que hizo el municipio para que realizaran cada uno un cortejo que celebrase el nombramiento arzobispal de Luis de Borbón en 1742, pero se convertiría en un conflicto a raíz de los festejos de celebración de la llegada al trono de Fernando VI en 1746. En esa ocasión la actividad de los de Santo Domingo y de San Ignacio se inició con los pregones elaborados por los estudiantes de ambas comunidades que anunciaban futuras mascaradas, que hizo el colegio de Santo Tomás el día 8 de noviembre, y el de los jesuitas el día 9. Por la tarde y noche de esos días, llevarían ambos colegios un víctor de gala, con acompañamiento de galas y coches, mediante los cuales presentaron unas tarjetas a la ciudad, que mandó colocar. En ambos pregones se anunciaban futuras máscaras más elaboradas. De hecho, el 27 de febrero según Matute 
sacarían los jesuitas una mascarada titulada la Fábula de Cadmo, mientras que para finales del mes de junio serían los dominicos los que compondrían un conjunto de nueve carros para su propio cortejo.

Pues bien, el paso de tales cortejos sería objeto de una intensa literatura manuscrita e impresa que daría lugar entre unos y otros a al menos veinticinco escritos, donde se cruzarían afirmaciones, críticas y burlas entre los amigos, estudiantes y miembros de ambas comunidades. ${ }^{44}$

Sus implicaciones festivas dejarían entrever aspectos de la construcción mental del contrario en un contexto histórico específico. A los dominicos se les suponía una fuerza extraordinaria hacia el papado, y aparecerían atisbos de crítica hacia la escolástica tradicional, señalando irónicamente la denegación eclesiástica de alguno de los textos dominicos. El grado en que este encono se hizo intenso se observa al constatar el apoyo dado por los estudiantes de Santo Tomás a fray Lucas Ramírez Galán, lector de Teología en el convento de San Antonio de la ciudad, defensor de la Summa de Santo Tomás, y para el que organizarían sus estudiantes un víctor de gala como consecuencia de las alegaciones realizadas a favor de los escritos del Padre de la Iglesia. El contexto cultural y eclesiástico de la época se observa en otras críticas realizadas a los de Santo Tomás por comportarse como «una especie de franco massones mythológicos» y entenderse como amigos de los enemigos de España ${ }^{45}$-Viena e Inglaterra-, y el uso de argumentos propios de la interpretación jansenista de la espiritualidad. ${ }^{46}$

Pero también la Compañía de Jesús soportaría críticas feroces por parte del otro bando de la disputa. Se destacaba su capacidad para ambicionar cada vez un mayor poder social, acogiéndose al favor de las señoras de posición, y la búsqueda desmesurada de una mejor posición económica. ${ }^{47}$

Sobre el propio desarrollo de los cortejos respectivos, se cruzan en la citada documentación múltiples descripciones y críticas, que revelan aspectos interesantes de la preparación y actividad de las mascaradas. Siguiendo los criterios aristotélicos, el decoro -su falta- aparece como uno de los defectos graves en el desarrollo de las mascaradas colegiales.

Se señalaba la ausencia de esta regla hacia el exterior, al confundirse por ejemplo, el saludo protocolario entre las instituciones de la Real Audiencia y de la corporación municipal, error que se suponía había cometido la máscara

44. Inventariados y recopilados en su mayoría con el texto íntegro en Biblioteca Nacional Colección de pregones, cartas y folletos relativos a las fiestas celebradas en Sevilla con motivo de la proclamación del rey d. Fernando VI. 1747 Biblioteca Nacional, R/23380, en adelante BN, y citamos las páginas del documento donde se sitúa cada impreso mencionado.

45. BN. Gazeta de Madrid de 31 de enero de 1747, pp. 255-266 cita en 255.

46. BN. Respuesta anticipada a algunos puntos que toca el papel que se aguarda del colegito de Santo Tomás, que contra los Reales Decretos, se nombra repetidas veces Mayor y en el que reproducen con mayor extensión y menos apariencia las imposturas que se habian publicado contra los jesuitas, p. 169-172.

47. BN. Habiendo visto un oficial de taberna desde el mostrador de su taberna al pregón de los estudiantes jesuitas escruió las siguientes coplas llebado de aquel adagio el que es de tu oficio es tu enemigo, pp. 37-40. 
jesuita, según varios impresos..$^{48}$ Esta falta de decoro se observa igualmente en el exceso de formas, como en la mímica desaforada de algún figurante, o en la acusación de licenciosos para los movimientos de los personajes, como los sátiros incluidos en la máscara de san Hermenegildo. ${ }^{49}$

Los principales elementos de fricción correspondían, sin embargo, a la ausencia de correspondencia en los contenidos de la máscara. A veces por la situación en un mismo plano de los símbolos religiosos con los aspectos graciosos de la mascarada, como se observa al disponerse el escudo de la orden religiosa de Santo Domingo en un carro burlesco, ${ }^{50}$ o como se acusa a los jesuitas, en aplicar unas letras eucarísticas en honor del rey: «En Pan y Vino se muestra / hoy la ley del gran Fernando / Gran misterio de su amor /, gran amor de sus vasallos» que los partidarios de los dominicos consideran poco apropiadas para la exaltación de un monarca humano. ${ }^{51}$ También el decoro afecta a nociones de carácter civil, como que un vencido turco portase en la mascarada jesuita la bandera de España o en la aparición de personajes no correspondientes con la historia mitológica, como el perro situado en el carro de la fábula de Baco y del que tuvo que defenderse el cortejo de san Hermenegildo. ${ }^{52}$

Interesantes son especialmente las acusaciones relacionadas con el propio proceso de conformación de la máscara, donde se considera en mayor o menor medida como un falseo de las reglas de juego en la creación del cortejo, el empleo de figuras o personajes ajenos a la institución que la patrocina y configura. Así, se critica el uso de figurantes y actores traídos ex profeso y externos a los propios colegios, como los armados de la Puerta Macarena, ${ }^{53}$ o el uso de cocheros de oficio para conducir los carros. ${ }^{54} \mathrm{~A}$ los dominicos se les acusa de «agregar amigos y aficionados» al cortejo e incluso que se sumen mozos de tienda a la máscara. Precisamente ese partido favorable a los jesuitas se burla del uso indiscriminado de los elementos populares del Corpus, que los de la orden de predicadores incorporan a su mascarada: la tarasca muy «estropeada»-pues se les acusó de romperla en su recorrido-,

48. BN. Correción fraterna a las notas marginales que en tono de responso ha cantado un caballero de la ciudad por responder a la censura y fee de erratas que dio a la carta suya otro caballero desapacionado en las quales se contienen varios retaços de Lengua portuguesa, Francesa y Castellana a lo antiguo; Latín macarrónico, diversas baratijas de mondongo, ventosidades, albardajo, bomitadura, interrogaciones, admiraciones, puntas redondos, qnadrados , y a parte, 69-80.

49. BN. Segunda carta de un estudiante Garci Pérez de Nabajas al mismo Vicario de la ciudad de N. segundo diálogo del mismo con el autor de las notas marginales en contrapunto al papel intitulado:correción fraterna etc... pp. 53-66 16 diciembre 1746.

50. En de Santo Domingo, en la crítica de opinión favorable a los jesuitas BN Capítulo de una carta escrita por un caballero a otro de esta ciudad de Sevilla quién le daba quenta de lo acaecido en ella durante en la proclamación del Señor Fernando VI 43-46 (manuscrito).

51. BN. Tercera carta de el estudiante Garci Pérez de Navajas al Vicario de N, 149-162 Se recoge en 157.

52. BN. Tercera carta, 159.

53. A los jesuitas en BN Habiendo visto un oficial de taberna desde el mostrador de su taberna al pregón de los estudiantes jesuitas escruió las siguientes coplas llebado de aquel adagio el que es de tu oficio es tu enemigo, 37-40.

54. BN. Corrección fraterna a las notas marginales, 69-80. 
el Padre Pando, Madre papahuevos, los papahuevillos, y otras figuras festivas que se emplearon en la máscara y que procedían de la procesión religiosa eucarística. ${ }^{55}$ Por ello, se decía que los dominicos habían hecho un Corpus para su pregón -mediante el uso de los elementos de la procesión- mientras que querían entonces hacer con la máscara una Semana Santa, por la abundancia de «telas para sayas, ropillas, golillas, acabando con todos los oficios mecánicos de Sevilla». 56

Todo este proceso concluiría con la recopilación de los textos acusatorios emitidos en Sevilla y la intervención, según Matute, de autoridad superior, que mandó finalizar la polémica. ${ }^{57}$

Esta disputa colegial tendría amplias consecuencias para el sentido de la fiesta. El difícil equilibrio entre el desarrollo erudito y finalista de sus contenidos con la exposición de sus apartados jocosos, constituía sin embargo una característica fundamental para la pervivencia de la propia celebración: si los contenidos «serios»de la máscara manifestaban la capacidad erudita para construir la alegoría, y con ello la aptitud de sus patrocinadores para jugar con las referencias al mundo antiguo y clásico, el aparato jocoso permitía atraer hacia la máscara a la masa popular y convertirla en un espectáculo público de primera magnitud. Como se indicaba para el pregón jocoso de la mascarada del Piadoso Eneas, junto con su carácter de anuncio del cortejo «que previamente tuviessen todos alguna especie de los que de passo esperaban mirar sus ojos», pues se buscaba que «el vulgo hallasse algún sainete con que paladearse para ver con gusto lo serio y grave de la función» ${ }^{58}$ Se trataba de una fiesta, por tanto, caracterizada por la discriminación semántica en su recepción por los diferentes grupos culturales y sociales que acudían a presenciar el espectáculo. $^{59}$

Precisamente, la polémica entre las «escuelas» se interpretaría como una manifestación clara de la dificultad por ejercer el dominio sobre los aspectos más abiertos, lúdicos o graciosos de la celebración, lo que suponía en definitiva reconocer la incapacidad de la autoridad -municipal, patrocinadora o censora- por ejercer el dominio sobre la fiesta, y desde el punto de vista de su capacidad comunicativa, la ruptura entre el deseo de condensar los aspectos diversos de la mascarada en una alegoría unitaria y efectiva.

De este modo, el pensamiento ilustrado encontrará una brecha abierta para desarrollar su crítica sobre el espectáculo e incorporar al mismo sus propias reformas. No es de extrañar que cuando Cándido María Trigueros desarrolle su propia invención para la mascarada de los Diez Gremios con motivo de la paz

55. BN El horno de las brujas. Aparición del bachiller Porreño a Garci Pérez de Nabajas, pp. 223-232.

56. BN Gazeta de Madrid de 31 de enero de 1747, pp. 255-266, p. 261.

57. «la emulación de las Escuelas, nacida de la oposición de sus doctrinas, dio origen a una guerrilla literaria, en que apartidados los profesores y afectos, dieron a luz, junta con su erudición, una gran parte de su bílis, que dio motivo a que mano superior detuviese sus ímpetus» (MATUTE: Anales, II, 1747, 5).

58. El piadoso Eneas de las Españas.... Sevilla : Viuda de Francisco Leefdael, 1729, fol 5.

59. Término de Portús: M. Morán Turina, J. Portús PÉrez: El arte de mirar. La pintura y su público en la España de Velázquez. Madrid: Istmo, 1997. 
con Inglaterra y el nacimiento de los infantes Carlos y Felipe, se especifique la decidida opción por potenciar los aspectos más serios y grandiosos que dieran solemnidad a la función:

Como el asunto de estos Regocijos era de suio tan digno y grandioso, se procuró desde luego que en su execución no tuviese cosa alguna que no fuese digna de tal asunto. La que en otras ocasiones de Máscara suele llamarse gracejo, y es propiamente bufonada i chocarrería, pareció que sería absolutamente indigna, no menos del asunto que se celebraba que de los sugetos que concurrían, i se procuró por tanto que todo se enderezase a lo grande i magestuoso. ${ }^{60}$

Sin duda, la preferencia por la majestuosidad determinó un alejamiento progresivo de la máscara con el espectáculo popular, pese a que los intentos de claridad en la forma y el entendimiento propios del pensamiento ilustrado quisieran dirigirse en sentido contrario. No es extraño que el propio Alenda, por otra parte partidario de la acción depuradora de Trigueros, señalase mucho años más tarde el exceso de motes latinos poco entendibles por el pueblo, en la comentada mascarada, y que en el contexto festivo en general se quejasen los autores de las relaciones de la sequedad a que conducía esa limitación de lo anecdótico y de su trasunto metafórico en la fiesta finisecular, como hiciera Antonio González de León cuando denunciara «la sequedad y desnudez moderna que no presenta otra cosa que aspectos y fachadas mudas, como pudieran verse en un cuaderno de estampas o de dibujos» haciendo a los pueblos «más arquitectos, que sabios ni eruditos». ${ }^{61}$

Pese a ello, la crítica transmitida desde el poder y los publicistas ilustrados terminaría por delimitar el carácter de la celebración «reformada». Así, y pese a la aparente victoria que suponía para las mascaradas tomistas el camino allanado por la supresión de los jesuitas y de su actividad colegial, cronistas de la época como Matute critican en las mismas el mantenimiento de los aspectos tradicionales, como en la ocasión del advenimiento del reinado de Carlos IV en 1789, cuando este autor indica de la máscara de los dominicos «que no obstante que careció de alusión e idea, el conjunto de sus figuras dio mucho que reír al populacho y que criticar a las personas sensatas». ${ }^{62}$

Contrasta la visión desfavorable de los cortejos tomistas con la opinión de los organizados por la universidad, el organismo reformado que se potencia como patrocinador de las máscaras en este momento, en torno a sencillas alegorías, la exaltación de las virtudes del progreso y la Razón y de la idea del monarca

60. Trigueros, Cándido María: Relación de las fiestas... con motivo de la ratificación de la paz, i del venturoso nacimiento de los serenísimos infantes gemelos Don Carlos, i Don Felipe, Sevilla: Oficina de Don Manuel Nicolás Vázquez y Compañía, 1784. Citado por Alenda, J.: Relación de solemnidades y fiestas públicas en España. Madrid: Sucesores de Rivadeneyra, 1903, Tomo II, 2167.

61. GonzÁlez De León, A.: Relación del adorno con que celebraron los Diez Gremios unidos de esta ciudad la entrada de los reyes nuestros señores Don Carlos IIII y Doña Luisa de Borbón. Sevilla: Oficina de Hijos de Hidalgo y González de la Bonilla, 1796.

62. Matute, Anales, III, 1789, 8 
como gran benefactor, bajo la idea estética de la contenida «discreción» con que se definen las organizadas por este centro docente en la proclamación de Carlos IV en 1789 y en la visita de los reyes a la ciudad en $1796 .{ }^{63}$ Con estos ejemplos, y con esa limitación de los aspectos extraordinarios y expresivos, se incidía en la racionalización «a lo serio» del festejo, y con ello en la consecuente herida de muerte, mediante el desequilibrio, de una fiesta barroca concebida y ejecutada en la ambivalencia entre la reflexión erudita y el espectáculo para los sentidos.

Anexo. Relación de mascaradas importantes en la Ciudad de Sevilla. SIGLOS XVII Y XVIII

1610, 13 de febrero. Máscara del Colegio de San Hermenegildo para celebrar la beatificación de Ignacio de Loyola. Se trataba de diez cuadrillas de estudiantes del colegio a caballo, anunciada por dos grupos previos de aventureros y salvajes, acompañados por otras figuras jocosas. La cuadrilla primera era la de las divinidades del saber -Apolo y las Musas, Minerva y Palas-, seguidos por los Inventores de las Letras y los Inventores de las Ciencias, Gramática, Poesía, Retórica, Astrología, Geometría, Filosofía, para finalizar con la Teología, representada por los Padres de la Iglesia y el Papa. El cortejo se adornaba con música de atabales y ministriles. ${ }^{64}$

1617, 26 y 27 de enero. Máscara de los estudiantes de Santa María de Jesús para celebrar el breve pontificio favorable a la devoción a la Inmaculada Concepción. El primer día tuvo lugar un paseo a modo de pregón de la máscara de profesores, doctores y estudiantes. En el segundo, el día de la mascarada, esta era introducida por salvajes y niño a caballo, que portaban el estandarte y estatutos de la universidad. Participaron seis cuadrillas: una primera de aventureros de la antigua caballería, junto con otras dedicadas a las disciplinas de la Gramática, las Artes, la Matemática y Filosofía natural, la Medicina, la Jurisprudencia y la Teología, desarrollada por estudiantes procedentes de las Canarias y rematada por un carro triunfal con un altar de la Inmaculada Concepción. ${ }^{65}$

1617, 19 de octubre. Máscara de cirujanos y barberos con ocasión del breve papal favorable a la devoción a la Inmaculada Concepción de María. Representaba una cuadrilla una boda villana, y otra con la ascendencia

63. Matute, Anales, ini, 1796, 24.

64. LuQue Fajardo, F.: Relación de la fiesta que se hizo en Sevilla a la beatificacion del glorioso S. Ignacio fundador de la Compañia de Iesus, Luis Estupiñán, 1610; AlendA: Relación, I, 522; MARTíN, M. ${ }^{a}$ BERnAL, «Algunas máscaras jesuitas del Siglo de Oro» TeatrEsco n. 1 (2005-2006).

65. Menéndez Peláez, J.: «Máscaras quijotescas, danzas y otras representaciones en el teatro escolar del siglo XVII español» en Archivum, n. 50-51 (2000-2001) pp. 451-484; SANZ: Fiestas sevillanas de la Inmaculada Concepción..., 2008. Estudia esta fiesta y las siguientes, donde comenta los principales impresos que sirven de fuentes para las mismas. 
de Cristo, siguiendo el evangelio de san Mateo. Aparecieran en ella inquisidores, arzobispos, órdenes militares, etc. «pensamiento aprobado en todo de todos». ${ }^{66}$

1617, 23 de octubre. Gran máscara de mercaderes y del convento de mercedarios. Salió desde el convento casa grande de la Merced, y recorrió diversos lugares de la ciudad. Estaba compuesta por siete cuadrillas, la primera representada por doce salvajes, la segunda por turcos, la tercera por comendadores de las órdenes militares, seguidos por otra con emperadores romanos, el séquito de Fernando el Católico, los Doce pares de Francia, y Doce tribus de Israel. El cortejo cerraba con Duns Scoto como defensor del futuro dogma. La mascarada era acompañada por la caballería de la ciudad, con hachas y con música de clarines, chirimías y atabales. ${ }^{67}$

1617. Máscara de gorreros y sederos en forma de torneo y celebrada en las gradas de la actual calle de Alemanes. ${ }^{68}$

1617, 26 de noviembre. Máscara concepcionista organizada por los plateros, y compuesta por seis cuadrillas, llevando música de clarines y trompetas. La máscara comenzaba por figuras que representaban la ciudad de Sevilla, acompañada y sostenida por Hércules y Julio César. Seguían seis cuadrillas formadas por distintos sujetos alegóricos o históricos que eran acompañamiento de un personaje o figura principal. La primera cuadrilla era de doce emperadores romanos, la segunda de negros, la tercera de caciques, la cuarta de potentados franceses con su rey, la quinta del reino de Portugal, con su alta aristocracia y reyes; la sexta semejaba el grupo de la curia que había recomendado el breve papal, con el acompañamiento de Mateo Vázquez de Leca y Bernando del Toro, los promotores sevillanos de la creencia. Su recorrido se inició desde el Alcázar, pasando por la plaza de San Francisco, Colcheros, Alameda, Amor de Dios, Sierpes, Gallegos, plaza del Salvador, Francos y vuelta por las Gradas de la catedral. ${ }^{69}$

1624, 4 de marzo. Máscara con motivo de la estancia real de Felipe IV. La mascarada hizo carrera en el patio del alcázar y de allí salió al resto de la ciudad. Por motivo del tiempo litúrgico, solo se permitió lucir cincuenta parejas de caballeros vestidos con ricas galas y acompañados por un número reducido de lacayos. En ella participaron «caballeros y títulos», siendo los vestidos «negros, mangas de tela, toquillas, vandas y plumas de diferentes colores». ${ }^{70}$

66. Alenda: Relación, I, 684; SAnZ: Fiestas sevillanas de la Inmaculada Concepción... 2008.

67. Ibidem.

68. Ortiz De Zúñiga: Anales, Tomo iv, 276; Sanz: Fiestas sevillanas de la Inmaculada Concepción, 2008.

69. SAnZ, M. ${ }^{a}$ J.: «El problema de la Inmaculada Concepción en la segunda década del siglo XVII. Festejos y máscaras. El papel de los plateros» en Laboratorio de Arte, 8, 1995, pp. 73-101; Fiestas sevillanas de la Inmaculada Concepción, 2008.

70. Ortiz De Zuñiga, D., con adiciones de A. Espinosa Y CÁrCel: Anales eclesiásticos y seculares de la Muy Noble y Muy Leal ciudad de Sevilla. Madrid: Imprenta Real, 1796, tomo IV, p. 308; AlendA: Relación, I, 846; F. J. Pizarro Gómez: «La entrada triunfal y la ciudad en los siglos XVI y XVII» en Espacio, 
1638, 19 de septiembre. Máscara del conde de Salvatierra, asistente de la ciudad, de los títulos y caballeros de la ciudad para celebrar la victoria de Fuenterrabia sobre la armada francesa. Se hicieron luminarias, se decretó una fiesta de acción de gracias y una fiesta real que pretendía unirse a las celebraciones por el futuro e inminente parto de la reina. ${ }^{71}$

1661. Máscara del Colegio de Santo Tomás para festejar el nacimiento del príncipe Carlos José. ${ }^{72}$

1671. Mascarada joco-seria con motivo de la canonización de Fernando III. ${ }^{73}$

1675. Hubo máscaras con motivo de la mayoría de edad del rey: mascaradas por la Universidad de Santa María de Jesús, por el Colegio de Santo Tomás, por el de San Hermenegildo, por el gremio de Espaderos, y por la Hermandad de los Negritos. ${ }^{74}$

1683, 28 de noviembre. Mascarada organizada por la Hermandad Sacramental del Sagrario de la catedral para celebrar el levantamiento del cerco de Viena y victoria sobre los turcos. Hizo un recorrido por la ciudad siguiendo la estación del Corpus. El cortejo se componía de gigantes vestidos de turco, ministriles, el guión de la sacramental portado por niños, así como la propia hermandad, con las danzas de la espada, cascabel y saraos. Los niños seises cantaron en la procesión. La máscara incluía un carro alegórico -la nave de la iglesia-, supuestamente llevado por los vencidos. En su interior se disponían armas y trofeos, la personificación de la ciudad liberada y los personajes más destacados de la victoria: el papa, el emperador, el rey y príncipe de Polonia, así como el gobernador de Viena, conde de Staremberg. ${ }^{75}$

1683, 3 de diciembre. Máscara organizada por el Colegio de San Hermenegildo de la Compañía de Jesús para celebrar la victoria en Viena frente a los

Tiempo y Forma, Serie VII, Historia del Arte, t. 4, 1991, pp. 121-134, Morales Martínez, A. J.: La ciudad transfigurada: fiestas en la Sevilla de Alonso Cano», en Symposium Internacional Alonso Cano y su época. Granada: Junta de Andalucía, Consejería de Cultura, 2002, pp. 237-247. Para esa ocasión preparó una máscara el Colegio de Santa María de Jesús, que probablemente no llegara a hacer su salida (TeatrEsco. Base de Datos online Catálogo Antiguo Teatro Escolar Hispánico. Ficha 822. http://147.156.0.116/fmi/iwp/ cgi?-db=Catalogo-Antiguo-Teatro-Escolar_Server\&-loadframes (Citamos como Catálogo Antiguo Teatro Escolar).

71. Alenda: Relación, I, 1020.

72. Catálogo Antiguo Teatro Escolar Hispánico, Ficha 1100.

73. Ortiz De Zúñiga: Anales, tomo v, 249.

74. F. Godoy: Lucido aparato, festivas demonstraciones con que la siempre Nobilissima, siempre muy Leal Ciudad de Sevilla manifestó la ilustre, la popular alegría, motivada de aver cumplido los catorce años de su edad el..., Católico Monarca de Jas Españas, Don Carlos Segundo, Sevilla: ; Heroyco aplavso, celebres jvbilos de lvstrosas demonstraciones, assi de festines. . . que el inuicto cabildo de la siempre muy noble y muy leal civdad de Sevilla, ha hecho, explicado ... el augusto gozo de aver cvmplido los catorze Años de sv edad el inuictissimo, y católico monarca de la Españas Don Carlos Segvndo Sevilla: Juan Cabeças, 1675; ORTIZ DE Zúñiga: Anales, Tomo V, 304-305, Alenda: Relación, I, 1366.

75. Martín Braones, A.: Lyrica relacion de la fiesta que la Ilustrissima Hermandad... del Samtiss.mo Sacramento en el Templo del señor San Clemente, Sagrario de la Iglesia Catedral... hizo en accion de gracias de la celebre victoria con que favoreciô Dios nuestro Señor las Armas del señor Emperador. Sevilla, 1683; Lorenzo Bautista de Zuñiga: Annales eclesiásticos y seglares de la... ciudad de Sevilla... que comprenden la Olimpiada o Lustro de la Corte en ella. Sevilla: F. J. de Blas Y QueSAdA, 1748, Prólogo, 1683. J. J. GarCía BERNAL: «Lo serio y lo burlesco». 
turcos. El cortejo burlesco de la máscara estuvo formado por dos carros, con la fábula de Vulcano y Marte en el primero y de Baco en el segundo de ellos. Se parodió al enemigo mediante un fingido cuerpo de soldados otomanos. La parte seria de la mascarada estaba presidida por un niño capitán, al que seguían diez cuadrillas y un carro con la fábula de Plutón y Proserpina y las figuras de las Parcas. ${ }^{76}$

1691, 27 de abril. Mascarada en forma de paseo de los caballeros maestrantes para celebrar la recobrada salud del rey. Los caballeros estaban organizados formando veintiuna cuadrillas, con personajes y colores variados. Matute señala como día de esta máscara el 3 de septiembre, cuando hubo máscara de guía con hachas donde asistió el alguacil mayor de la ciudad con doce lacayos, el asistente conde de Montellano, vestido de color a la francesa con lacayos, acompañando a las parejas maestrantes. ${ }^{77}$

1704, 3 de febrero. Máscara del Colegio de Santo Tomás, para celebrar el casamiento del monarca. Contaba con un solo carro triunfal, con el retrato del rey «forrado por la espalda en forma de manto con rico terciopelo y galones de oro». Hubo alumnos a caballo, con ricas ropas y sombreros con plumajes. Tras ellos, un grupo de ninfas también ecuestre, con la principal de ellas representando a la reina. También se dispuso una parte jocosa, con cuartetas situada a la espalda de miembros del cortejo. ${ }^{78}$

1704, 30 de agosto. Máscara de la Real Maestranza, con motivo de la victoria de la armada del conde de Tolosa. Hubo salvas, hogueras, y en la plaza de San Francisco un baile por la tarde, y carreras de los maestrantes por la noche. ${ }^{79}$

1707, 3 de septiembre. Nacimiento del príncipe Luis de Borbón. La noticia llegó a la ciudad el 29 de agosto, convocándose luminarias en toda la ciudad. Se hizo máscara de la tropa con hachas de cera y gala, conduciendo un carro «muy adornado con las efigies del Rey y Reina, la de una matrona que les presentaba al Príncipe, a cuyos lados iban otros dos personajes que figuraban al Cardenal de Toledo y al Patriarca». ${ }^{80}$

1707, 11 de septiembre. Paseo de gala de la Real Maestranza de Caballería, con los caballos enjaezados, servidos por criados, y otros con hachas de cera que iluminaban la carrera. Fueron a la casa del asistente conde de Miraflores a cumplimentarle. ${ }^{81}$

1707, 23 de septiembre. Máscara de los Sastres, con ocasión del nacimiento del príncipe de Asturias, cortejo que«fue aplaudido», y que portaba el estandarte del rey Fernando. ${ }^{82}$

76. Descripción de la máscara con que el día tres de diciembre del Apóstol de la India San Francisco Xavier, solemnizaron la victoria de las armas católicas los estudiantes del Colegio de San Hermenegildo de la Compañía de Jesús de Sevilla. Sevilla: Juan Vejarano, 1683; GArcía Bernal, J. J.: «Lo serio y lo burlesco». 77. Alenda: Relación, I, 1518.

78. Matute, Anales, I, 1704, 2; Alenda, Relación, I, 1669.

79. Matute: Anales, I, 1704, 8; Alenda: Relación, I, 1020.

80. Matute: Anales, I, 1704, 12.

81.Matute: Anales, I, 1707, 12; Alenda: Relación, I, 1687.

82. Alenda: Relación, I, 1687. 
1707, 9 de octubre. Máscara organizada por el Colegio de Santo Tomás con motivo del nacimiento del príncipe. Esta institución sacó un Paseo jocoserio. Alenda la describe como una gran máscara dividida en una parte «festiva á lo ridículo, ó mojiganga», compuesta por seis cuadrillas, con asuntos jocosos, y otra seria, formada por seis cuadrillas y dos carros, donde «en medio de lujoso aparato, se dejaban ver alegorías alusivas al objeto de la fiesta».83

1707, 5 de noviembre. El Colegio de San Hermenegildo sacó a las calles una máscara titulada Hércules, fundador de Sevilla, de la que fue autor el profesor jesuita Juan Vicente Ramos. La máscara fue anunciada previamente dos días antes, en tono jocoso, por un estudiante montado en un burro. El cortejo central estuvo formado por comparsas de estudiantes, de las que representaba por medio de ninfas, la Gramática, la Retórica, la Filosofía y la Teología. Salieron además siete carros, cuyas cuadrillas iban unas con trajes burlescos, y otras representando a personajes mitológicos e históricos. El primero de ellos servía de prólogo a la función; el segundo representaba a Hércules en la cuna, despedazando a las dos culebras que Juno le arroja; el tercero, el mismo con el gigante y la hidra; el cuarto, el triunfo de Hércules cuando sacó del infierno a Teseo; el quinto, la fundación de Sevilla; en el sexto iban los músicos, acompañados por el duque de Alba y Alejandro de Farnesio, vestidos a la moda de sus países; finalmente, el séptimo, «que era el Real», representaba una corte con caballeros españoles y franceses. Una loa se insertaba en el cortejo desde uno de los carros con un contenido al efecto del cortejo. ${ }^{84}$

1707. Los asturianos de la ciudad sacaron una mojiganga, con éxito de público. ${ }^{85}$

1713, 23 y 24 de junio. Hubo una mascarada organizada por el Colegio de Santo Tomás para celebrar la canonización de Pío V. El pregón, de carácter cómico, recorrió las calles de la ciudad el primero de esos días, y durante la tarde del siguiente desfiló la comitiva seria de la mascarada. ${ }^{86}$

1729, 4 de febrero. Máscara paseo de la Real Maestranza por la noche, con asistencia de ochenta lacayos y cuarenta caballeros maestrantes, que partieron desde la morada del Hermano Mayor de la corporación, el marqués de las Torres, y se dirigieron por la Campana, San Acasio, Sierpes, plaza de San Francisco, Génova, Gradas, Arquillo de San Miguel hasta el Alcázar, haciendo demostraciones de dominio ecuestre. ${ }^{87}$

83. Zuñiga, L. B. de: Annales eclesiásticos y seglares de la... ciudad de Sevilla... que comprenden la Olimpiada o Lustro de la Corte en ella. Sevilla: F. J. de Blas Y Quesada, 1748, prólogo, 1707; Alenda: Relación, I, 1669; C. BuEzo: Prácticas festivas en el teatro breve del siglo XVII. Kassel : Reichenberger, 2004. 84. Fabula Heroyca: Hercules fundador de Sevilla : celebración festiva al felicissimo natal del Principe de las Asturias ... Luis I. Sevilla: Francisco Leefdael, 1707; AlendA: Relación, I, 1668. Catálogo Antiguo Teatro Escolar, Ficha 684.

85. Matute: Anales, I, 1707, 12.

86. Ibidem, 8.

87. Freneva, G. F.: Veridica narración de un puntual diario, describiendo los célebres aplausos, festivos júbilos, y heroycas diversiones, que en ... Sevilla han tenido los Catholicos Reyes, Principes è Infantes, desde 
1729, abril y mayo. Máscaras organizadas por los Diez Gremios, por los estudiantes de Santo Tomás, por la Compañía de Jesús, las patrocinadas por el gremio de zapateros, y las del gremio de sastres, estas dos últimas con seguro recorrido por la plaza de San Francisco. ${ }^{88}$

1729. Máscara del gremio de la sastrería, con el tema de la piedad de Eneas que pasó por los campos elíseos a ver a su padre Anquises, alegoría del paso del monarca por Sevilla para visitar el cuerpo de su antepasado san Fernando. Tras un pregón de tipo burlesco, la máscara propiamente dicha contaba con cuadrilla con turcos, caballería a la española y una escuadra a la antigua de los antiguos sastres, vestidos a la cuchilla conforme a una pretérita concesión real. Acompañaban a un carro con la representación de los campos elíseos. Frente al carro, paseaba el pendón real que conserva el gremio, mientras actuaban como escolta varios guardias. La máscara tenía la pretensión de cantar unas letras en presencia de sus majestades, salir el día 2 de mayo, pero finalmente no pudo llevarse a efecto en ese día. ${ }^{89}$

1742, 8 de enero. El colegio de San Hermenegildo sacó una máscara, la Fábula heroica de Teseo, con cinco carros y dieciocho cuadrillas entre serias y jocosas. El pregón lo iniciaron en tono jocoso los estudiantes mediante un romance. La máscara se componía de dos carros serios dedicados a la muerte del Minotauro y la liberación de los atenienses, y a la dedicación que hace Teseo de Atenas a la diosa Atenea, teniendo como metáfora del ofrecimiento de su alteza Luis de Borbón que ofrece a Atenas-Sevilla el estudio de las ciencias. La parte jocosa estuvo compuesta por un carro con un risco con la Fama, la Ignorancia ciega y la Envidia, y un segundo con el dibujo de un edificio, con la representación del laberinto de Creta, y Venus, con dos niños representando el tributo que debía pagar Atenas, así como las dos princesas, Ariadna y Fedra. Acompañaban a los carros jocosos niños y jóvenes con tarjetas y como maravillas de la Antigüedad. El último carro tenía por tema la dedicación de Atenas y la coronación de Teseo. En su recorrido del 11 de enero de 1742 pasó por el barrio deel Duque, la Campana, calle de Sierpe, plaza de San Francisco, calle Genova, y Gradas hasta el palacio arzobispal, donde entro en un patio y se introdujo en un palenque cercano construido al efecto. ${ }^{90}$

su feliz entrada en ella el el dia 2 de febrero de este año de 1729, hasta el dia 31 de mayo del mismo año .. Sevilla: Viuda de Francisco de Leefdael, 1729.

88. Ams. Sec. V. Tomo 303. 6; Márquez Redondo, A. G.: Sevilla, ciudad y Corte (1729-1733). Sevilla: Ayuntamiento, 1994.

89. El piadoso Eneas de las Españas : solemne alegórica demonstración de regocijo, con que aplauden, y celebran la feliz venida de los Reyes Católicos a esta muy Noble, y Leal Ciudad de Sevilla los maestros de sastrería residentes en la misma ciudad ... Sevilla : Viuda de Francisco Leefdael, 1729.

90. Relación universal de las festivas demonstraciones que se han hecho en la muy noble y muy leal ciudad de Sevilla para celebrar el solemne triduo de la posessión que por el Ilustrísimo Señor Infante Cardenal Don Luis Antonio Jayme de Borbón tomo del arzobispado el Ilustrísimo Señor Don Gabriel Torres. Sevilla: Imp. Antonio de Espinosa, 1742. 
1742, abril y mayo. Máscara organizada por el Colegio de Santo Tomás por la posesión del cardenal don Luis de Borbón del arzobispado de Sevilla. Su pregón, de dos comitivas, una jocosa y otra seria, tuvo lugar el 18 de abril, recorriendo calles de Sevilla y Triana. El cortejo principal de la máscara salió el día 2 de mayo, con la presencia de cuatro carros e ingeniosas cuadrillas. Formaban su séquito una cuadrilla con un carro burlesco con un ameno bosque donde se situaban la diosa Hebe, Vitula y Volupia, y los dioses Príapo y Momo; la segunda parte de la mascarada estaba formada por la cuadrilla alrededor de un carro alegórico del pensil de la iglesia, donde sobresalía la flor de lis borbónica, construido a modo de galera, con los dioses Alcinoo, Pomona, Flora y Jano. El tercer carro, de tono serio, era el trono de Júpiter, con Ceres, Diana y Venus, y finalmente un carro con pabellón, con Titán, Cibeles, a cuyos pies estaban situados Marte, Minerva, Apolo, Neptuno, Juno, Astrea y Mercurio, representando a la familia real, Roma y el cardenal Aquaviva. El espectáculo colegial finalizaba con un víctor de gala que salió a las calles el 3 de mayo. El recorrido de la máscara, que se estima similar al que se describe para el víctor, se dirigió hacia el sur para bordear la Universidad de Santa María de Jesús, para luego pasar tras la catedral, y desde las Gradas dirigirse por Génova hasta la plaza de San Francisco. Desde allí posiblemente se dirigió por la calle del Ángel (Rioja) hacia el convento de San Pablo y salir por la Puerta de Triana hacia el Arenal. Entró de nuevo en la ciudad por la Puerta del Arenal, para seguir la calle de la Mar y dirigirse de vuelta al Colegio de Santo Tomás. Su publicación se dedicó al cabildo eclesiástico, y se ilustró con cuatro láminas de Domingo Martínez grabadas por Agustín Moreno. ${ }^{91}$

1746. Con motivo de la proclamación de Fernando VI, días 8 y 9 de noviembre, los colegios de Santo Tomás y de San Hermenegildo sacaron una máscara, con cuadrillas serias y jocosas, como pregón de la que sacarían al próximo año. Dice Matute que por la tarde condujeron un víctor con acompañamiento de hachas y coches que presentaron a la ciudad, y que mandó colocar «en sitio digno y correspondiente a su urbanidad». ${ }^{92}$

1747. La máscara de los gitanos fue pregonada el 30 de noviembre de 1746, y tuvo efecto el 11 de febrero de 1747, con la idea de representar la conquista de México y la prisión de Montezuma. Abría una tropa seguida por figurantes con traje de ministros. Seguía una comitiva a pie y montada en burros, tras la cual venían dos danzas, de Gitanitas y de Mozas grandes, que pretendían glosar la danza de Montezuma. Tenía un carro con la representación de Cortés y sus soldados rindiendo al emperador azteca, con los retratos de Carlos V y Fernando VI, seguido de seis jinetes con arcos y carcaj. ${ }^{93}$

91. Bolaños y De los Reyes Peña: Una mascarada joco-seria.

92. Biblioteca Nacional, R/23380 Colección de pregones; MATUTE: Anales, II, 1746, 7.

93. Matute: Anales, II, 1747, 3; Alenda: Relación, II, 1979. 
1747. Tras el pregón del festejo del 9 de noviembre de 1746, el 27 de febrero del año siguiente salió la máscara del Colegio de San Hermenegildo, en que se representó la Fábula de Cadmo, con seis magníficos carros «que no cabiendo por los arquillos de San Miguel ni de la Contratación o Casa de la Moneda, no pudo ir a la Universidad, y el cabildo eclesiástico lo colocó en la Puerta del Perdón, donde las cuadrillas de baile, música y canto lucieron su destreza». La relación explica su alegoría general como una exaltación de Júpiter. Se iniciaba con las figuras del escudo real y otros personajes jocosos. El primer carro jocoso es el de Cadmo, seguido por cuadrillas de artes y letras. En la parte seria la victoria sobre la oscuridad. Un carro con Apolo y sus musas, y otro principal con las figuras de Júpiter y Juno, aproado por la victoria. Siguen los carros de Jano, dios de la paz y la guerra, y el de Plutón, dios de la justicia. Tras los alumnos del colegio de la Concepción, el último carro es el de Neptuno y su corte marina. ${ }^{94}$

1747. La máscara del Colegio de Santo Tomás sacó el pregón primero de su máscara el 8 de noviembre de 1746, y un segundo de gala el día 19 de junio, anunciando una máscara para el 30 de ese mes. En ella sacó nueve carros con invenciones. La competencia entre los colegios de dominicos y jesuitas derivó ese año en una oposición literaria unida a las divergencias de doctrinas entre ambos institutos religiosos, que sería finalmente detenida por orden eclesiástica. ${ }^{95}$

1747, 7 de mayo. Los estudiantes dominicos hicieron un víctor de gala en honor del teólogo sevillano fray Lucas Ramírez, que condujeron en un coche el 7 de ese mes, acompañados por caballos enjaezados, y ellos con bonetes con insignias y colores de la facultad. ${ }^{96}$

1747, junio. Máscara de la Real Fábrica de Tabacos. Dice Matute que estaba en la casa de los Tavera de la calle Real de San Marcos. El festejo fue organizado por el director de la fábrica, don José de Losada y Prada. Su anuncio salió a la calle el 30 de noviembre de 1746 con el carro del pregón. El 27 de junio de 1747 fue el cortejo principal, compuesto por seis carros, dedicados a la Común Alegría, a cada uno de los cuatro elementos y al Parnaso. Los carros eran acompañados de cuadrillas de música y bailes, y con ingeniosas invenciones, con una diversidad de representaciones que recogía un auténtico mundo abreviado. Posteriormente hubo un víctor de gala el día 29 , donde sacaron dos carros, el primero de los cuales que portaba tres tarjetas, presentadas a la ciudad, al asistente y al administrador de la Fábri-

94. Noticia previa, y conducente para la mas prompta, y facil inteligencia de la Mascara que en el presente día sale de la Compañía de Jesús... en celebridad de la Exaltación al trono de... Don Fernando sexto el Benigno... Sevilla: Imprenta de la universidad en las Siete Revueltas, 1747?. Zuñ IGA: Annales eclesiásticos y seglares de la... ciudad de Sevilla... que comprenden la Olimpiada, 247-248; Márquez Redondo, A. G.: El ayuntamiento de Sevilla en el siglo XVIII. Sevilla: Ayuntamiento, 2010, tomo I, pp. 589 y nota 19, donde refiere las relaciones de las máscaras de ese año.

95. ZuÑIgA: Annales eclesiásticos y seglares de la... ciudad de Sevilla... que comprenden la Olimpiada, 247-248; Matute: Anales, II, 1747, 5 y 8

96. Matute: Anales, II, 1747, 8. 
ca, y en el segundo unos retratos de los reyes que regalaron al cabildo civil en la plaza de San Francisco, correspondiendo este acto al momento más destacado de su recorrido. La mascarada partió de la plaza de San Juan de la Palma, incorporándose al itinerario festivo más recurrente de la ciudad, con su paso por el Arco de San Miguel, calle Génova, Gradas de la catedral, hasta llegar a la citada plaza. Se encargó a Domingo Martínez la realización de ocho cuadros con la representación de los carros en diversos lugares del itinerario de la máscara, serie que sería finalizada por sus discípulos y que se conserva en el museo de Bellas Artes de la ciudad. ${ }^{97}$

1749, 25 de junio. Coadministrador del arzobispado a Francisco de Solis Foch de Cardona. Víctor de gala en su honor organizado por el Colegio de Santo Tomás el 25 de abril, que fue presentado al prelado en la mañana de ese día en el palacio arzobispal de la ciudad con la representación de un melodrama encomiástico «de las virtudes del héroe a quién se dirigía este obsequio». La función se repetiría en el Colegio escolástico. ${ }^{98}$

1749. Máscara con la fábula de Júpiter y Europa, organizada por el Colegio de San Hermenegildo. ${ }^{99}$

1784, 17 de enero. Máscara organizada por los Diez Gremios con motivo del nacimiento de los infantes Carlos y Felipe y la firma de la paz con Inglaterra. Encargaron a Cándido M. Trigueros la idea y su desarrollo literario. La máscara de los gremios debía componerse de doce cuadrillas, representando un triunfo al estilo romano. Fueron figuras principales el Vigor, o fuerza española, la Navegación, comercio, y fama, con varios carros. Su víctor consistió en una única cuadrilla con máscaras y un solo carro, desde el cual unos albañiles bajaban un lienzo con inscripción conmemorativa, mientras se recitaban versos y una orquesta tocaba desde el carro. El recorrido de la máscara incluía la plaza de San Francisco, en donde pasó por «por el grandioso arco triunfal //32 que estaba y se conserva quasi acabado i debía colocarse en la plaza de San Francisco, acia la Real Audiencia» frente a la calle Sierpes. ${ }^{100}$

1789, abril. Máscara de la Universidad literaria, cortejo denominado El triunfo de la sabiduría sobre el error, que tuvo lugar los días 21 y 22 de ese mes. Según Matute, estaba formada por un carro con faetón y el águila, tirado por caballos enjaezados, con una cuadrilla que representaban estudiantes, instrumentos musicales, vicios y virtudes y grupos de danza. Tras esta parte del cortejo, estaba el carro con la representación del templo de la Sabiduría, que representaba un drama entre ciencias y saberes (Sabiduría, Teología,

97. CANSINo, R.: Nuevo mapa: descripcion iconologica del mundo abreviado: Real máscara de simbolicos triumphos en festiva ostentacion del mas plausible culto por medio de los quatro elementos que ofrecio la... mui leal ciudad de Sevilla en la exaltacion à el throno... de nuestro catholico monarcha... Fernando VI. Sevilla: 1751; Matute: Anales, II, 1747, 6; Pizarro Y Viña: «La Máscara del mundo abreviado de Sevilla», 2000. MORALES: «Imagen urbana y fiesta pública en Sevilla», 2005.

98. Matute, Anales, iI, 1747, 10. Catálogo Antiguo Teatro Escolar, Ficha 480.

99. Catálogo Antiguo Teatro Escolar, Ficha 2447.

100. Trigueros, Cándido María: Relación de las fiestas, 1784; AlendA: Relación, II, 2160. 
Jurisprudencia, Medicina, Matemática, Filosofía, las tres Nobles Artes, la Industria). Los personajes representaron «un oportuno y discreto drama delante del ayuntamiento, y las comparsas bailaron graciosas contradanzas en un palenque elevado al intento» arrojando a su término monedas con el busto del rey y lemas alusivos. Los bailes se repetirían en el Alcázar, y estos y el drama delante del atrio de la puerta grande de la catedral y para el arzobispo, en un tablado construido para ello delante de su palacio. ${ }^{101}$

1789, abril. Máscara del Colegio de Santo Tomás. Pregón en la tarde del 18 de abril, «sin alusión e idea» de modo que «el conjunto de sus figuras dio mucho que reir al populacho y que criticar a las personas sensatas» según Matute. La máscara era un paseo de gala de un carro triunfal que conducía el retrato de los reyes, al que acompañaba un séquito de figurantes simulando la corte, órdenes militares españolas y la de Malta. En el carro además había varios personajes que ocupaban el papel de las ciencias y las artes. Tras él había una comparsa que ejecutaba una contradanza, y que soltaba pajarillos pintados, mientras que una parte del festejo correspondía a un «melodrama cómico, representado sobre un carro triunfal en la plaza de San Francisco». El rector de la universidad arrojó al pueblo monedas con lemas alusivos. El éxito fue tal que a petición del procurador mayor de la ciudad, la comparsa ofreció su danza de nuevo en el palenque construido en la plaza de San Francisco para la proclamación, mientras que el drama incorporado a la mascarada, un diálogo entre las artes, sería representado en las galerías del ayuntamiento, donde tenía dispuesto el banquete el municipio. ${ }^{102}$

1796. 28 de febrero. Máscara de la Universidad literaria con motivo de la estancia del rey Carlos IV en la ciudad. Matute la calificó de «discreta». Un carro que figuraba como el de Salomón condujo una inscripción ofrecida por las ciencias para honrar la entrada de los reyes en el patio del Real Alcázar. Cuatro cuadrillas cada una con ocho parejas bailaron diversas danzas acompañados por veinticuatro músicos enmascarados, siendo una de ellas de tipo pastoril, bailada con panderetas y sonajas «que dio mucho gusto». La máscara se dirigió a la puerta grande de la catedral, donde representaron los bailes delante del cabildo y arzobispo, y en la plaza de San Francisco, donde hicieron la misma representación ante el asistente y el cabildo civil. ${ }^{103}$

101. Matute, Anales, III, 1789, 8; Ruiz Lagos: Cultura simbólica e Ilustración andaluza, 1985.

102. Descripción de la Máscara, ó paseo de gala con q u e los alumnos del Colegio Mayor de $S$ a $n$ to Tomas de Aquino celebraron la exaltación al trono de su Augusto Monarca el Señor Don Carlos IV... Sevilla: Vázquez, Hidalgo y Cía, 1789; MATUte, Anales, III, 1789.

103. Matute: Anales, III, 1796, 24. 